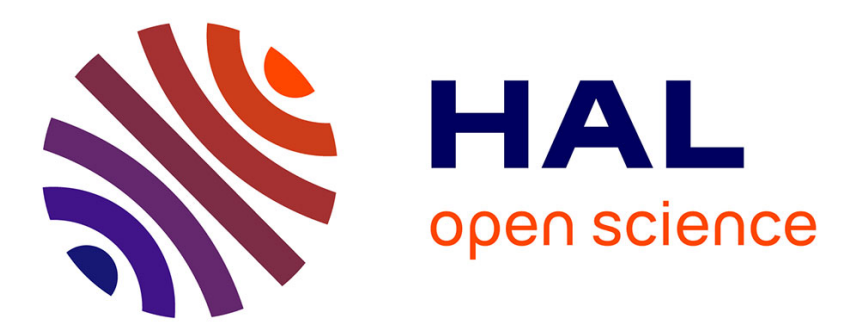

\title{
Mineralogy and genesis of smectites in an alkaline-saline environment of Pantanal wetland, Brazil
}

Sheila Aparecida Correia Furquim, Robert C Graham, Laurent Barbiero, José Pereira de Queiroz Neto, Vincent Valles

\section{- To cite this version:}

Sheila Aparecida Correia Furquim, Robert C Graham, Laurent Barbiero, José Pereira de Queiroz Neto, Vincent Valles. Mineralogy and genesis of smectites in an alkaline-saline environment of Pantanal wetland, Brazil. Clays and Clay Minerals, 2008, 56 (5), pp.579-595. 10.1346/CCMN.2008.0560511 . hal-02079999

\section{HAL Id: hal-02079999 \\ https://hal.science/hal-02079999}

Submitted on 26 Mar 2019

HAL is a multi-disciplinary open access archive for the deposit and dissemination of scientific research documents, whether they are published or not. The documents may come from teaching and research institutions in France or abroad, or from public or private research centers.
L'archive ouverte pluridisciplinaire HAL, est destinée au dépôt et à la diffusion de documents scientifiques de niveau recherche, publiés ou non, émanant des établissements d'enseignement et de recherche français ou étrangers, des laboratoires publics ou privés. 


\section{MINERALOGY AND GENESIS OF SMECTITES IN AN ALKALINE-SALINE ENVIRONMENT OF PANTANAL WETLAND, BRAZIL.}

Sheila Aparecida Correia Furquim ${ }^{1 *}$, Robert C. Graham ${ }^{2}$, Laurent Barbiero ${ }^{3}$, José Pereira de Queiroz Neto $^{1}$, Vincent Valles ${ }^{4}$

1 - Laboratório de Pedologia, Departamento de Geografia, Universidade de São Paulo (USP), Av. Prof. Dr. Lineu Prestes, 338, 05508-900, São Paulo, Brazil.

2 - Soil \& Water Sciences Program, Department of Environmental Sciences, University of California, Riverside, CA 92521-0424, USA.

3 - Laboratoire des Mécanismes de Transfert en Géologie, UMR 5563 CNRS-IRD-UPS-OMP, 14 Av. E. Belin, 31400, Toulouse, France.

4 - Laboratoire d'Hydrogéologie, Université d'Avignon et des Pays du Vaucluse, 74 Rue Louis Pasteur, 84029, Avignon, France.

Short running title: Genesis of smectites in an alkaline-saline environment

Address correspondence to: Sheila Aparecida Correia Furquim

corresponding author: sfurquim@usp.br

\section{ABSTRACT}

Smectite formation in alkaline-saline environments has been attributed to direct precipitation from solution and/or transformation from precursor minerals, but these mechanisms are not universally agreed upon in the literature. The objective of this work was to investigate the mineralogy of smectites in the soils surrounding a representative alkaline-saline lake of Nhecolândia, a sub-region of the Pantanal wetland, and then to identify the mechanisms of their formation. Soils were sampled along a toposequence and analyzed by XRD, TEM-EDS, and ICP-MS. Water was collected along a transect involving the studied toposequence and equilibrium diagrams were calculated using the databases PHREEQC and AQUA. The fine clay fraction is dominated by smectite, mica, and kaolinite. Smectites are concentrated at two places in the toposequence: an upper zone, which includes the soil horizons rarely reached by the lake level variation; and a lower zone, which includes the surface horizon within the area of seasonal lake level variation. Within the upper zone, the smectite is dioctahedral, rich in $\mathrm{Al}$ and $\mathrm{Fe}$, and is classified as ferribeidellite. This phase is interstratified with mica and vermiculite and has an Fe content similar to that of the identified mica. These characteristics suggest that the ferribeidellite originates from transformation of micas and that vermiculite is an intermediate phase in this transformation. Within the lower zone, smectites are dominantly trioctahedral, Mg-rich, and are saponitic and stevensitic minerals. In addition, samples enriched in these minerals have much lower REE contents than other soil samples. Water chemistry shows a geochemical control of $\mathrm{Mg}$ and saturation with respect to Mg-smectites in the more saline waters. REE contents, water chemistry, and the presence of $\mathrm{Mg}$-smectite where maximum evaporation is expected suggest that saponitic and stevensitic minerals originate by chemical precipitation from the water column of the alkaline-saline lake.

Key words: neoformation, chemical precipitation, transformation, ferribeidellite, mica-smectite interstratification, $\mathrm{Mg}$-smectite, trioctahedral smectite, saline lake. 


\section{INTRODUCTION}

Smectites are commonly reported in soils and sediments associated with alkaline-saline lakes subjected to concentration by evaporation. The formation of these minerals in alkaline-saline environments has been described as a function of the concentration factor and the amount of detrital material available. According to Darragi and Tardy (1987), in a gradient ranging from the least to the most concentrated solution and from the most to the least detrital input, the sequence of smectite formation would be beidellite, saponite, and stevensite ${ }^{1}$. Based on these conclusions, dioctahedral Alrich beidellite would be primarily allogenic or formed through transformation of detrital materials, while trioctahedral Mg-rich stevensite would be formed by precipitation from concentrated aqueous solutions, inasmuch as the availability of precursor materials for transformation is minimal. Although it has been widely accepted that authigenic ${ }^{2}$ dioctahedral smectites, such as montmorillonite and beidellite, are commonly formed by transformation from precursor clay minerals in alkaline-saline lakes (Gac et al., 1977; Torrez Ruiz et al., 1994; Mayayo et al., 2000; Cuevas et al., 2003), genesis of saponite and stevensite in these environments has been attributed either to precipitation from solution (Tettenhorst and Moore, 1978; Darragi and Tardy, 1987; Torrez Ruiz et al., 1994; Mayayo et al., 2000; Akbulut and Kadir, 2003) or to transformation of precursor clays (Banfield et al., 1991; Pozo and Casas, 1999; Mayayo et al., 2000; Cuevas et al., 2003). The last process seems contrary to the general idea of stevensite formation proposed by Darragi and Tardy (1987), but is in agreement with the observation of Jones (1986), who pointed out that formation of clay minerals in lake environments is more commonly by transformation than by precipitation. Discrimination of neoformed clays has been a difficult task in alkaline evaporative environments because these sites usually are clay-enriched areas by virtue of their low landscape positions (Hillier, 1995). Moreover, although the geochemical control of $\mathrm{Mg}$ from the solution is significant, the quantity of precipitated Mg-clays is generally low compared to the amount of clay already present in the soil profile. The Nhecolândia is a sub-region of the Pantanal wetland, the largest wetland complex in the world (Por, 1995), mostly located in western Brazil (Figure 1). A distinctive feature of this sub-region is the presence of thousands of fresh and alkaline-saline lakes. These lakes exist in close proximity, yet display a huge chemical variability. The salinity has been attributed to inheritance from the past (Tricart, 1982; Ab'Saber, 1988; and others), but more recently Barbiero et al. $(2002,2007)$ have shown that saline water arises from present-day evaporative concentration of fresh water. Statistical analysis of the major elements in a regional context indicated that two independent processes are probably responsible for most of the chemical variability between fresh and saline waters: precipitation of calcite or $\mathrm{Mg}$-calcite and formation of $\mathrm{Mg}$-silicates as solutions become more saline (Barbiero et al., 2002). The lakes of Nhecolândia offer a good opportunity to study phyllosilicates in modern alkaline-saline environments because most of the sediments and soils are very sandy (Cunha, 1980; Amaral Filho, 1986), which facilitates the discrimination of neoformed clays. In spite of these advantages and the huge size of Pantanal wetland, the mineralogy of the materials related to the alkaline-saline lakes is still unknown. In this context, the objectives of this research were to study the mineralogy of smectites associated with a representative alkaline-saline lake of Nhecolândia and to identify the mechanisms responsible for their formation.

\section{ENVIRONMENTAL SETTING}

\footnotetext{
${ }^{1}$ Formulas provided by Darragi and Tardy (1987) - Beidellite: $\mathrm{Ca}_{0.3}\left(\mathrm{Al}_{1.2} \mathrm{Fe}^{3+}{ }_{0.4} \mathrm{Mg}_{0.6}\right)\left(\mathrm{Si}_{3.6} \mathrm{Al}_{0.4}\right) \mathrm{O}_{10}(\mathrm{OH})_{2} ; \mathrm{Saponite}: \mathrm{Na}_{0.4}$ $\left(\mathrm{Al}_{0.6} \mathrm{Fe}_{0.2} \mathrm{Mg}_{1.8}\right)\left(\mathrm{Si}_{3.8} \mathrm{Al}_{0.2}\right) \mathrm{O}_{10}(\mathrm{OH})_{2}$; and Stevensite: $\mathrm{Na}_{0.2}\left(\mathrm{Al}_{0.3} \mathrm{Fe}_{0.1} \mathrm{Mg}_{2.3}\right)\left(\mathrm{Si}_{4}\right) \mathrm{O}_{10}(\mathrm{OH})_{2}$.

${ }^{2}$ In the present work, the term authigenesis includes both neoformational and transformational reactions in which new minerals are formed (Jeans, 1984).
} 
The Pantanal wetland is a huge and still active alluvial plain situated between $15^{\circ}$ and $22^{\circ} \mathrm{S}$ and $55^{\circ}$ and $60^{\circ} \mathrm{W}$, with a total area of about $200000 \mathrm{~km}^{2}$. Characterized by extremely low slope gradients $(0.03$ to $0.50 \mathrm{~m} / \mathrm{km})$ and altitudes between 100 and $200 \mathrm{~m}$ (Silva, 1986; Scott, 1991), the plain is partially covered by seasonal flooding mainly in the summer (November to March). During the dry period, the flood areas are replaced by a complex mosaic of grasslands and forests dotted with thousands of lakes and marshes. Quaternary sediments underlying the wetland are alluvial deposits of the Paraguai River and tributaries, carried from surrounding escarpments, hills, and monadnocks (Del'Arco et al., 1982; Por, 1995). These highlands have altitudes between 200 and 900 meters and are composed of Precambrian crystalline rocks and Mesozoic sedimentary rocks (Alvarenga et al., 1984; Godoi Filho, 1986).

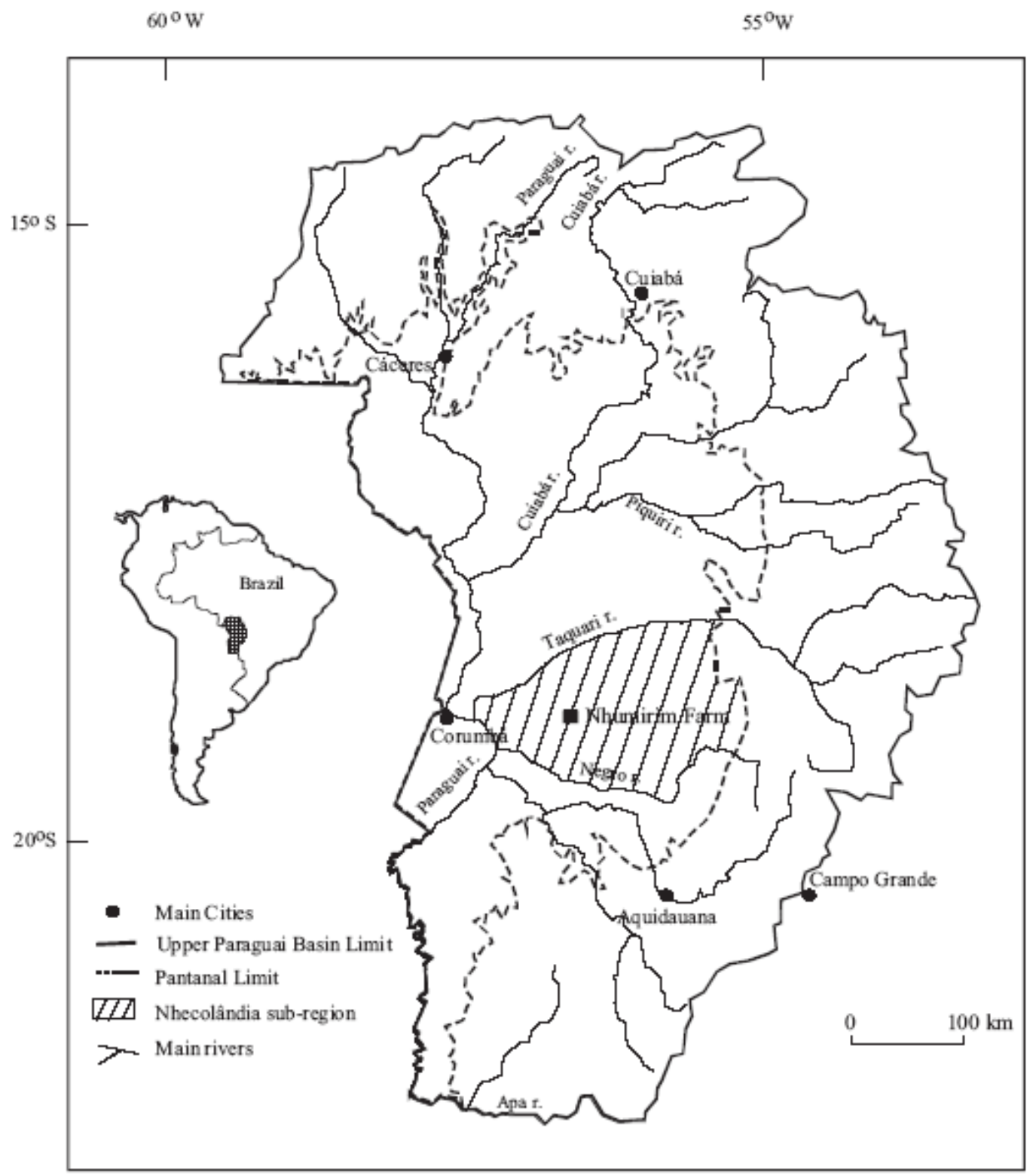

Figure 1. Location of Pantanal wetland, Nhecolândia sub-region, and Nhumirim Farm.

The Nhecolândia sub-region $\left(27000 \mathrm{~km}^{2}\right)$ is located in the central-southern part of the Pantanal wetland (Figure 1), on a huge alluvial fan dominated by sediments composed of $95 \%$ of sand (Cunha, 
1980). The dominant soil orders are Spodosols and Entisols, both with less than 15 wt $\%$ of clay in surface and subsurface horizons. There are also some associated sodic soils, with more than $15 \%$ of $\mathrm{Na}^{+}$in exchangeable sites (Cunha, 1980; Amaral Filho, 1986). The coexistence of freshwater ("baías") and alkaline-saline lakes ("salinas"), generally associated with temporary channels ("vazantes") and sand hills ("cordilheiras") (Figure 2), occurs only in the south-southwestern, lowland portion of Nhecolândia (Fernandes et al., 1999). These special features of the landscape will be referred to throughout the text, being defined as following: 1) Freshwater lakes ("baías") are temporary lakes with different forms and dimensions, up to $2 \mathrm{~m}$ deep. 2) Temporary channels ("vazantes") are formed by the coalescence of freshwater lakes during the flooding periods. They can be several kilometers long and 10 to $40 \mathrm{~m}$ wide. 3) Alkaline-saline lakes ("salinas") are permanent salt lakes that are generally 500 to $1000 \mathrm{~m}$ in diameter and 2 to $3 \mathrm{~m}$ deep. They are isolated rounded depressions located inside sand hills, occupying the lowest topographical position of the landscape. 4) Sand hills ("cordilheiras") are narrow, elongated, 2 to $3 \mathrm{~m}$ higher than the surrounding landscape and covered by dense savanna vegetation. These higher strips of dry land and the isolated salt lakes are fed by groundwater and, in general, are not reached by surface waters during flooding.

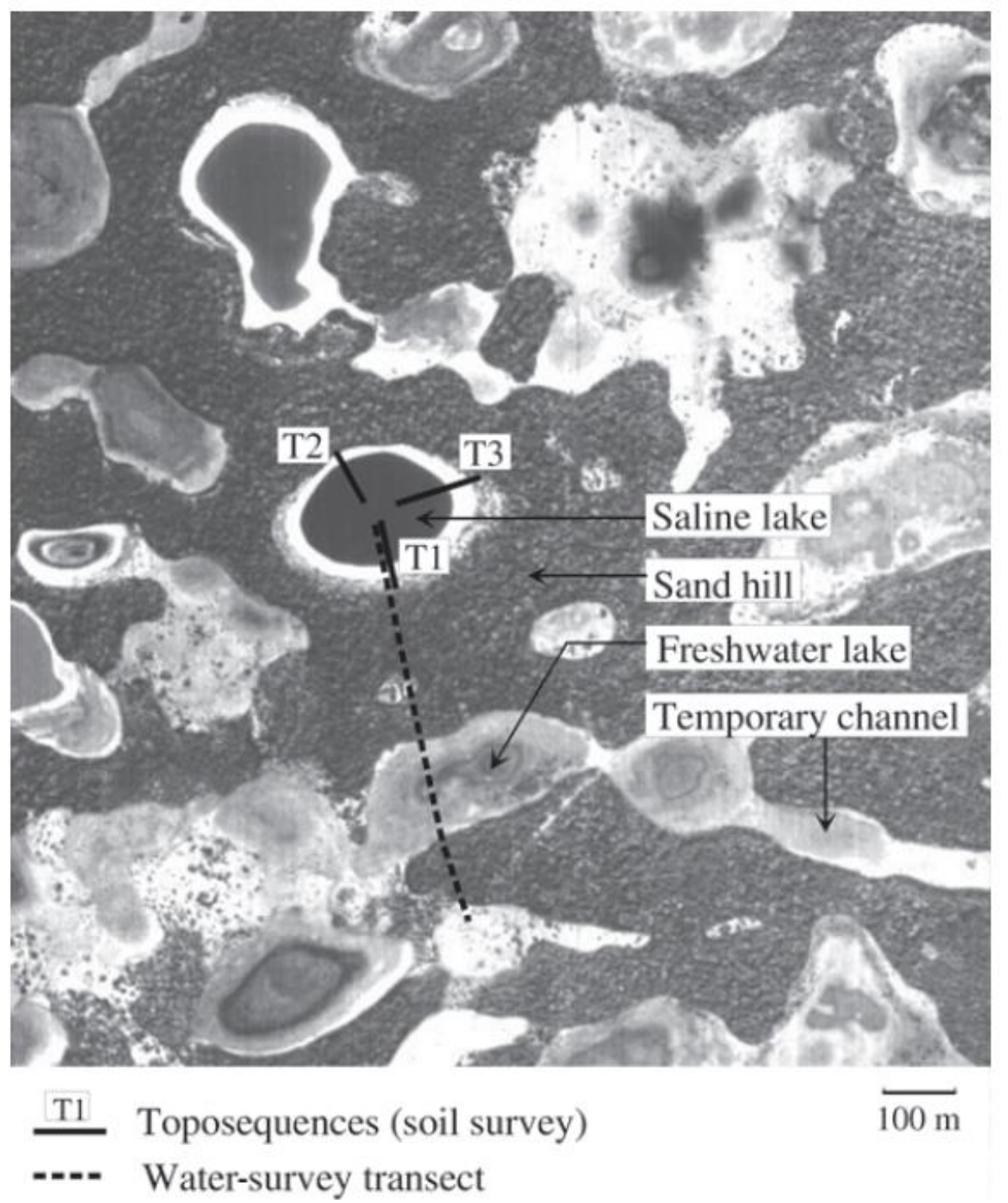

Figure 2. Aerial photograph showing the main landscape features of Nhecolândia, the surveyed toposequences around the studied alkaline-saline lake, and the water survey transect. 
A hypothesis of the groundwater flow connecting the different lakes has been described by Barbiero et al. (2007). The alkaline-saline lakes are surrounded by an impervious, green, sandy loam, Na-rich, subsurface horizon, which is frequently indurated by amorphous silica. During the wet season the watertable rises and moves from the freshwater lakes towards the alkaline-saline lake passing into and over the impervious sandy loam horizon. However, during the dry season, the watertable is lower and the sandy loam horizon acts as a barrier against the return flow of groundwater from the alkalinesaline lakes toward the freshwater lakes. Thus the water is continuously flowing towards the saline lake where it evaporates, increasing the ion activities. This model explains how saline and freshwater lakes coexist in close proximity having such different ion concentrations, inasmuch as they are subjected to the same amount of evaporation and rainfall. As a result, of the evaporative concentration process, a large geochemical variability between waters in this system has been observed (Barbiero et al., 2002; 2007). The less saline waters (freshwater lakes and temporary channels) have $\mathrm{pH}$ values near 5.5, electrical conductivity values of about $0.02 \mathrm{dS} / \mathrm{m}$, and a $\mathrm{CO}_{3}-\mathrm{Cl}$ and $\mathrm{Na}-\mathrm{K}$ chemical profile. On the other hand, the most saline waters (alkaline-saline lakes and surrounding watertable) have $\mathrm{pH}$ values ranging from 9.0 to 10.5 , electrical conductivities from 4 to $20 \mathrm{dS} / \mathrm{m}$, and a $\mathrm{CO}_{3}-\mathrm{Na}$ chemical profile. Furthermore, the most saline waters have significantly lower $\mathrm{Ca}^{2+}$ and $\mathrm{Mg}^{2+}$ activities.

In contrast to the arid and semi-arid conditions of the alkaline-saline lakes commonly reported in the literature, the lakes of Pantanal are in a tropical climate (Aw, according to Koeppen's classification). Mean annual temperature is about $22^{\circ} \mathrm{C}$ and mean annual precipitation is between 850 and $1100 \mathrm{~mm}$, being strongly concentrated in the summer (December to March). However, the wetland presents an annual hydrological deficit of at least $300 \mathrm{~mm}$, resulting from a mean annual evapotranspiration around $1400 \mathrm{~mm}$ (Por, 1995; Alfonsi and Camargo, 1986).

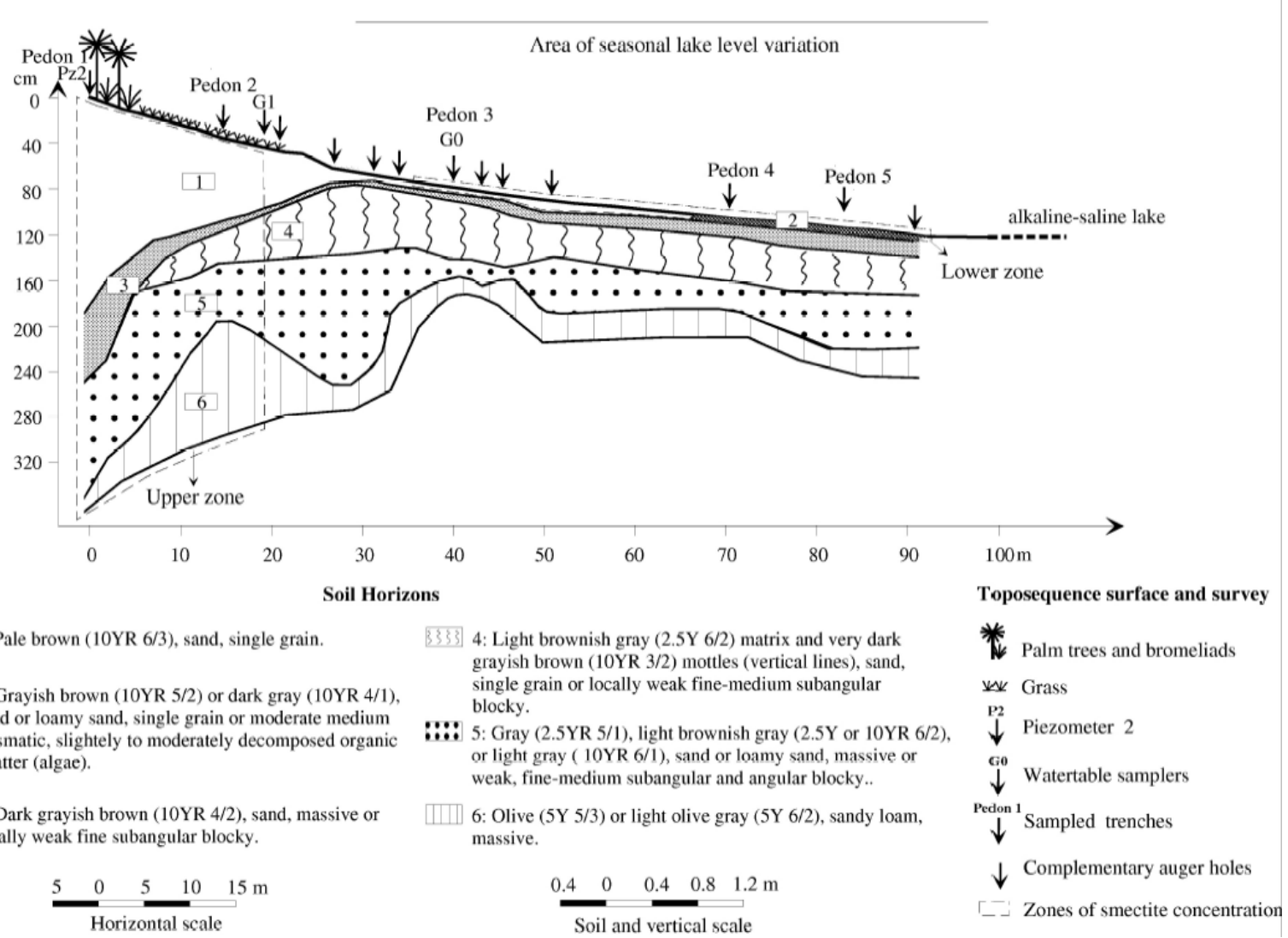

Figure 3. Soil distribution along toposequence T1. 
Table 1. Physical and chemical properties of soils along T1.

\begin{tabular}{|c|c|c|c|c|c|c|c|}
\hline Horizon & $\mathrm{pH}$ & $\mathrm{EC}^{*}(\mathrm{dS} / \mathrm{m})$ & $\begin{array}{c}\text { Sand (wt.\%) } \\
\text { Total }\end{array}$ & $\begin{array}{l}\text { Silt (wt.\%) } \\
\text { Total }\end{array}$ & Coarse & $\begin{array}{l}\text { y (wt.\%) } \\
\text { Fine }\end{array}$ & Total \\
\hline \multicolumn{8}{|l|}{ Pedon 1} \\
\hline 1 & 5.4 & 0.4 & 96.1 & 0.8 & 1.9 & 1.3 & 3.2 \\
\hline 3 & 9.9 & 6.8 & 83.4 & 5.0 & 8.6 & 3.1 & 11.7 \\
\hline 5 & 9.6 & 7.2 & 81.7 & 9.5 & 6.0 & 2.9 & 8.8 \\
\hline 6 & 9.5 & 4.7 & 70.6 & 10.5 & 10.9 & 8.0 & 18.9 \\
\hline \multicolumn{8}{|l|}{ Pedon 2} \\
\hline 1 & 8.1 & 0.3 & 95.7 & 1.4 & 2.8 & 0.1 & 2.9 \\
\hline 4 & 9.2 & 0.5 & 96.1 & 1.1 & 1.7 & 1.2 & 2.9 \\
\hline 5 & 10.5 & 11.5 & 89.9 & 4.5 & 4.8 & 0.8 & 5.6 \\
\hline 6 & 11.0 & 14.9 & 72.7 & 11.9 & 12.5 & 2.9 & 15.4 \\
\hline \multicolumn{8}{|l|}{ Pedon 3} \\
\hline 1 & 10.4 & 9.6 & 95.4 & 1.0 & 1.1 & 2.5 & 3.6 \\
\hline 4 & 10.2 & 17.7 & 93.2 & 3.1 & 1.7 & 2.0 & 3.7 \\
\hline 5 & 10.2 & 19.2 & 85.7 & 7.9 & 4.0 & 2.5 & 6.5 \\
\hline 6 & 10.6 & 17.7 & 74.3 & 12.5 & 8.9 & 4.3 & 13.3 \\
\hline \multicolumn{8}{|l|}{ Pedon 4} \\
\hline 2 & 10.3 & 30.3 & 94.6 & 1.8 & 2.1 & 1.5 & 3.6 \\
\hline 4 & 10.1 & 11.4 & 90.2 & 5.6 & 3.4 & 0.8 & 4.2 \\
\hline 5 & 10.8 & 13.3 & 88.2 & 6.8 & 3.4 & 1.6 & 5.0 \\
\hline 6 & 10.4 & 11.4 & 78.3 & 10.1 & 8.1 & 3.4 & 11.6 \\
\hline \multicolumn{8}{|l|}{ Pedon 5} \\
\hline 2 & 10.2 & 43.0 & 82.3 & 9.2 & 6.3 & 2.3 & 8.5 \\
\hline 4 & 10.4 & 9.8 & 90.2 & 6.4 & 1.9 & 1.5 & 3.4 \\
\hline 5 & 10.8 & 13.9 & 80.3 & 12.2 & 5.7 & 1.9 & 7.5 \\
\hline 6 & 10.6 & 13.2 & 76.2 & 13.8 & 7.7 & 2.3 & 9.9 \\
\hline
\end{tabular}

* EC $=$ Electrical conductivity

Table 2. Semi-quantitative mineral proportions in the fine-clay fraction.

\begin{tabular}{|c|c|c|c|c|c|c|}
\hline Horizon & Kaolinite & $\begin{array}{l}\text { Tinerals (se } \\
\text { Smectite }\end{array}$ & $\begin{array}{l}\text { litative, \%) } \\
\text { Mica }\end{array}$ & $\overline{\text { Quartz }}$ & $\begin{array}{l}\text { Dominant octahedral } \\
\text { sheet type of smectite }\end{array}$ & $\begin{array}{l}\text { Zones of smectite } \\
\text { concentration }\end{array}$ \\
\hline \multicolumn{7}{|l|}{ Pedon 1} \\
\hline 1 & 50 & 17 & 32 & 0 & Dioctahedral & Upper zone \\
\hline 3 & 34 & 40 & 26 & 0 & Dioctahedral & Upper zone \\
\hline 5 & 41 & 34 & 24 & 0 & Dioctahedral & Upper zone \\
\hline 6 & 49 & 50 & 1 & 0 & Dioctahedral & Upper zone \\
\hline \multicolumn{7}{|l|}{ Pedon 2} \\
\hline 1 & 36 & 10 & 51 & 3 & Dioctahedral & Upper zone \\
\hline 4 & 46 & 10 & 26 & 18 & Dioctahedral & Upper zone \\
\hline 5 & 49 & 11 & 40 & 0 & Dioctahedral & Upper zone \\
\hline 6 & 34 & 14 & 52 & 0 & Dioctahedral & Upper zone \\
\hline \multicolumn{7}{|l|}{ Pedon 3} \\
\hline 1 & 5 & 73 & 22 & 0 & Trioctahedral & Lower zone \\
\hline 4 & 53 & 6 & 23 & 18 & Dioctahedral & \\
\hline 5 & 29 & 0 & 71 & 0 & 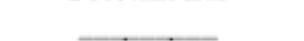 & \\
\hline 6 & 15 & 0 & 84 & 1 & & $\longrightarrow$ \\
\hline \multicolumn{7}{|l|}{ Pedon 4} \\
\hline 2 & 4 & 70 & 26 & 0 & Trioctahedral & Lower zone \\
\hline 4 & 29 & 0 & 71 & 0 & & \\
\hline 5 & 19 & 0 & 81 & 0 & & $\bar{x}$ \\
\hline 6 & 21 & 4 & 75 & 0 & $\widehat{\text { Dioctahedral }}$ & $\bar{\square}$ \\
\hline \multicolumn{7}{|l|}{ Pedon 5} \\
\hline 2 & 4 & 69 & 27 & 0 & Trioctahedral & Lower zone \\
\hline 4 & 36 & 10 & 47 & 7 & Dioctahedral & \\
\hline 5 & 24 & 0 & 67 & 9 & 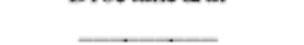 & - \\
\hline 6 & 16 & 0 & 84 & 0 & $\bar{x}$ & ?. \\
\hline
\end{tabular}


Table 3. Major elements (\%) in the fine-clay fraction, measured by ICP-MS.

\begin{tabular}{|c|c|c|c|c|c|c|c|c|c|c|c|}
\hline $\begin{array}{l}\text { Zones of smectite } \\
\text { concentration }\end{array}$ & Horizon & $\mathrm{Si}$ & $\mathrm{Al}$ & $\mathrm{Fe}$ & $\mathrm{Mn}$ & $\mathrm{Mg}$ & $\mathrm{Ca}$ & $\mathrm{Na}$ & $\mathrm{K}$ & $\mathrm{Ti}$ & $\mathrm{P}$ \\
\hline \multicolumn{12}{|l|}{ Pedon 1} \\
\hline Upper zone & 1 & 59.14 & 17.14 & 6.14 & 0.37 & 1.26 & 0.15 & 0.46 & 2.08 & 1.39 & 0.13 \\
\hline Upper zone & 3 & 52.63 & 20.37 & 9.20 & 0.12 & 1.70 & 0.09 & 0.72 & 2.03 & 0.68 & 0.07 \\
\hline Upper zone & 5 & 49.31 & 22.76 & 8.84 & 0.08 & 1.41 & 0.07 & 0.50 & 1.66 & 0.61 & 0.07 \\
\hline Upper zone & 6 & 49.81 & 21.91 & 9.43 & 0.06 & 1.37 & 0.08 & 0.84 & 1.41 & 0.59 & 0.06 \\
\hline \multicolumn{12}{|l|}{ Pedon 2} \\
\hline Upper zone & 4 & 62.87 & 15.18 & 5.52 & 0.36 & 1.35 & 0.15 & 0.72 & 2.96 & 1.95 & 0.08 \\
\hline Upper zone & 5 & 58.48 & 16.44 & 6.94 & 0.51 & 2.16 & 0.15 & 0.73 & 3.33 & 1.25 & 0.07 \\
\hline Upper zone & 6 & 51.49 & 18.84 & 8.93 & 0.20 & 1.91 & 0.06 & 1.48 & 3.48 & 0.50 & 0.07 \\
\hline \multicolumn{12}{|l|}{ Pedon 3} \\
\hline & 4 & 58.45 & 15.86 & 4.31 & 0.36 & 1.75 & 0.29 & 1.93 & 2.93 & 2.15 & 0.11 \\
\hline & 5 & 51.42 & 15.76 & 9.74 & 0.62 & 2.24 & 0.07 & 1.32 & 4.84 & 0.83 & 0.08 \\
\hline & 6 & 54.26 & 15.16 & 10.64 & 0.72 & 2.35 & 0.06 & 1.44 & 5.15 & 0.54 & 0.08 \\
\hline \multicolumn{12}{|l|}{ Pedon 4} \\
\hline \multirow{4}{*}{ Lower zone } & 2 & 50.57 & 3.75 & 3.40 & 2.69 & 15.04 & 1.21 & 0.12 & 1.15 & 0.22 & 0.23 \\
\hline & 4 & 54.63 & 11.79 & 5.86 & 6.28 & 2.77 & 0.37 & 0.19 & 3.82 & 1.28 & 0.09 \\
\hline & 5 & 53.03 & 15.76 & 9.65 & 0.42 & 3.00 & 0.09 & 1.16 & 4.87 & 0.48 & 0.10 \\
\hline & 6 & 54.86 & 14.68 & 9.04 & 0.74 & 2.61 & 0.15 & 0.33 & 4.12 & 0.69 & 0.09 \\
\hline \multicolumn{12}{|l|}{ Pedon 5} \\
\hline \multirow{4}{*}{ Lower zone } & 2 & 44.39 & 3.50 & 3.33 & 2.43 & 13.11 & 2.00 & 0.13 & 1.04 & 0.17 & 0.24 \\
\hline & 4 & 62.82 & 12.33 & 4.72 & 0.68 & 3.46 & 0.18 & 0.30 & 3.12 & 1.74 & 0.08 \\
\hline & 5 & 55.81 & 14.85 & 9.54 & 0.47 & 2.79 & 0.09 & 0.99 & 4.88 & 0.65 & 0.09 \\
\hline & 6 & 55.54 & 14.14 & 10.02 & 0.62 & 2.80 & 0.20 & 0.41 & 4.72 & 0.57 & 0.08 \\
\hline
\end{tabular}

\section{METHODS}

\section{Field work}

The study was carried out at the Nhumirim Farm (Figure 1), which is representative of Nhecolândia and managed by the Brazilian Institute for Agricultural Research (Embrapa-Pantanal). The soil morphology was studied in detail at the peak of the dry season (September and October) using auger holes and trenches along 3 toposequences (Figure 2). The toposequences extended from the surface water level of an alkaline-saline lake to the border of the local sand hill. Because soils along the 3 toposequences were very similar, only one (T1 - Figures 2 and 3) was chosen for soil sampling and subsequent laboratory analyses. A total of 20 soil samples from horizons of 5 pedons (listed in Tables 1 and 2) were collected from trenches along the 100 meter transect. A set of 15 piezometers has been installed since 1998 along a transect involving the studied alkaline-saline lake, the adjacent sand hill, and the neighbouring freshwater lake (Figure 2). In addition, 13 watertable samplers were set up along the same transect during the dry season of October 2000. Subsurface and surface waters were collected at several periods. The water sampling and analytical procedures were described by Barbiero et al. (2007), who also presented a detailed analysis of the water chemistry. The same set of data is used in the present study.

\section{Soil analyses}

The whole soil of the 20 collected samples was used to measure: 1) $\mathrm{pH}$ by the 1:1 soil:water method, using a Denver instrument UB-10; 2) Electrical conductivity (EC) on the saturated paste, using a compact Horiba C-173; 3) Particle size by the pipette method. Coarse $(2-0.2 \mu \mathrm{m})$ and fine clay $(<0.2 \mu \mathrm{m})$ fractions of the 20 samples were separated by centrifugation and sedimentation after destruction of the organic matter with $\mathrm{NaOCl}(\mathrm{pH} 9.5)$ (Anderson, 1963). These fractionated samples were used in soil analyses described henceforth. 
X-ray diffraction analyses (XRD) of oriented and randomly oriented specimens were made of both coarse and fine clay fractions of the 20 soil samples. Oriented specimens were obtained by smearing a paste on glass slides (Theisen and Harward, 1962) and analysed with five different treatments: $\mathrm{Mg}$ saturation kept at $52 \%$ of relative humidity, ethylene glycol solvation of $\mathrm{Mg}$-saturated clays, air-dried $\mathrm{K}$ saturation, and heating of the $\mathrm{K}$ saturated clays at $350^{\circ} \mathrm{C}$ and $550^{\circ} \mathrm{C}$ (Jackson, 1979). Randomly oriented specimens for measurement of $d_{060}$ values were achieved by side-packing freeze-dried clay powder in an aluminum sample holder. The analyses were carried out in a Siemens D-500 diffractometer $\left(\mathrm{CuK} \alpha\right.$ radiation with graphite crystal monochromator), using a step size of a $0.02^{\circ} 2 \theta$ and a count time of $1.0 \mathrm{~s}$ per step. Semi-quantitative estimations of mineral proportions of the fine clay fraction in each sample were determined based on the calculation of XRD peak area proportions on ethylene glycol patterns, following the procedures of Biscaye (1965).

Table 4. Oxides (wt.\%) and calculated chemical formulas of individual crystals of smectite.

\begin{tabular}{|c|c|c|c|c|c|c|}
\hline \multirow[b]{2}{*}{ Crystal number } & \multirow{2}{*}{$\begin{array}{c}\text { Pedon } 1-\text { horizon } 6 \\
\text { upper zone } \\
1\end{array}$} & \multicolumn{2}{|c|}{$\begin{array}{l}\text { Pedon } 4 \text { - horizon } 2 \\
\text { lower zone }\end{array}$} & \multicolumn{3}{|c|}{$\begin{array}{c}\text { — Pedon } 5-\text { horizon } 2- \\
\text { lower zone }\end{array}$} \\
\hline & & 2 & 3 & 4 & 5 & 6 \\
\hline $\mathrm{SiO}_{2}$ & 52.3 & 60.8 & 62.0 & 57.7 & 60.7 & 59.2 \\
\hline $\mathrm{Al}_{2} \mathrm{O}_{3}$ & 35.0 & 9.9 & 7.0 & 9.8 & 10.7 & 1.5 \\
\hline $\mathrm{Fe}_{2} \mathrm{O}_{3}$ & 10.0 & 6.2 & 6.3 & 3.7 & 4.2 & 3.7 \\
\hline $\mathrm{MgO}$ & 1.3 & 15.7 & 17.7 & 16.4 & 17.1 & 22.8 \\
\hline $\mathrm{CaO}$ & 0.8 & 1.5 & 1.2 & 2.5 & 1.3 & 2.9 \\
\hline $\mathrm{K}_{2} \mathrm{O}$ & 0.6 & 1.7 & 1.6 & 0.7 & 0.9 & 0.2 \\
\hline $\mathrm{Cl}$ & 0.0 & 1.4 & 1.3 & 6.2 & 2.4 & 5.7 \\
\hline $\mathrm{Si}$ & 3.18 & 3.88 & 3.96 & 3.86 & 3.87 & 4.01 \\
\hline $\mathrm{Al}$ & 0.82 & 0.12 & 0.04 & 0.14 & 0.13 & 0.00 \\
\hline$\Sigma$ tet. & 4.00 & 4.00 & 4.00 & 4.00 & 4.00 & 4.01 \\
\hline $\mathrm{Al}$ & 1.69 & 0.63 & 0.49 & 0.63 & 0.67 & 0.12 \\
\hline $\mathrm{Fe}$ & 0.46 & 0.30 & 0.30 & 0.19 & 0.20 & 0.19 \\
\hline $\mathrm{Mg}$ & 0.04 & 1.49 & 1.69 & 1.63 & 1.63 & 2.30 \\
\hline Eoct. & 2.19 & 2.42 & 2.48 & 2.45 & 2.50 & 2.61 \\
\hline $\mathrm{K}$ & 0.05 & 0.14 & 0.13 & 0.06 & 0.07 & 0.02 \\
\hline $\mathrm{Ca}$ & 0.05 & 0.10 & 0.08 & 0.18 & 0.09 & 0.21 \\
\hline $\mathrm{Mg}$ & 0.08 & 0.00 & 0.00 & 0.00 & 0.00 & 0.00 \\
\hline Anions - $\mathrm{O} 10$ & & & & & & \\
\hline $\mathrm{OH}$ & 2.00 & 0.85 & 1.86 & 1.30 & 1.74 & 1.35 \\
\hline $\mathrm{Cl}$ & 0.00 & 0.15 & 0.14 & 0.70 & 0.26 & 0.65 \\
\hline $\begin{array}{l}\text { Tetrahedral sheet } \\
\text { charge }\end{array}$ & -0.82 & -0.12 & -0.04 & -0.14 & -0.13 & 0.03 \\
\hline $\begin{array}{l}\text { Octahedral sheet } \\
\text { charge }\end{array}$ & 0.51 & -0.22 & -0.25 & -0.28 & -0.12 & -0.47 \\
\hline Total charge & -0.31 & -0.34 & -0.29 & -0.42 & -0.25 & -0.44 \\
\hline Interlayer charge & 0.31 & 0.34 & 0.29 & 0.42 & 0.25 & 0.44 \\
\hline
\end{tabular}

Quantitative analyses of major elements ( $\mathrm{Si}, \mathrm{Al}, \mathrm{Fe}, \mathrm{Mn}, \mathrm{Mg}, \mathrm{Ca}, \mathrm{Na}, \mathrm{K}, \mathrm{Ti}$, and $\mathrm{P}$ ) and rare earth elements-REE ( $\mathrm{La}, \mathrm{Ce}, \mathrm{Pr}, \mathrm{Nd}, \mathrm{Sm}, \mathrm{Eu}, \mathrm{Gd}, \mathrm{Tb}, \mathrm{Dy}, \mathrm{Ho}, \mathrm{Er}, \mathrm{Tm}, \mathrm{Yb}, \mathrm{Lu}$, and Y) were performed on the fine clay fraction of 18 samples (listed in Tables 3 and 5) by inductively coupled plasma-mass spectrometry (ICP-MS). REE contents have been normalized according to North America Shale Composition (NASC) (Gromet et al., 1984).

The fine clay fraction of 3 samples (listed in Table 4), selected due to the substantial proportion of smectites in the assemblages, was analysed using a FEI-CM300 transmission electron microscope (TEM) linked with an energy-dispersive X-ray microanalyser (EDS). For analysis, a drop of a dilute suspension containing the fine clay was placed on a standard $\mathrm{Cu}$ grid with carbon film. The chemical 
composition of 1 to 3 crystals of smectites was determined by EDS for each sample. The collected data were used to calculate the chemical formulas of the individual crystals. $\mathrm{Mg}$ amounts were maintained in the octahedral position in all calculated formulas, with the exception of one, where a minor part was attributed to the interlayer position to adjust to beidellite modal charge, which ranges from 0.30 to 0.35 (Weaver and Pollard, 1973). Mössbauer spectrometry data (not shown in the present work) revealed that $\mathrm{Fe}^{2+}$ amounts are $\leq 8 \%$ in these samples (R. Morris, pers. comm., 2006), therefore only $\mathrm{Fe}^{3+}$ was included in the formulas.

\section{Equilibrium diagram calculations}

The ionic speciation, activity, and the water saturation with respect to minerals were calculated using two databases, PHREEQC and AQUA (Parkhurst, 1995; Valles et al., 1996). Both are ion pair models built around the law of Debye-Huckel but differing from their extension for saline waters. PHREEQC is considering the Scatchard (1936) extension, which is the most commonly used, whereas AQUA is using a specific extension that takes into account the solvent/solute interactions under strong ionic strengths. Both PHREEQC and AQUA databases yielded very similar results. The choice of ion pair models is justified by the dominance of carbonates and bi-carbonates in the solution, which have propensity to form ion pairs, although some imprecision has to be expected with respect to the saturation of Na-carbonates or Na-silicates salts. During the modelling, the partial pressure of $\mathrm{CO}_{2}$ is calculated from the field-pH and from alkalinity data, while theoretically equilibrating $\mathrm{O}_{2}$ fugacity is calculated from field $\mathrm{pH}, \mathrm{Eh}$, and T. Saturation with respect to silicate minerals that commonly occurs in alkaline-saline environments was studied, such as for Mg-silicates types (stevensite, sepiolite saponite) and Na-silicates types (kenyaite, magadiite, and kanemite) (Gueddari, 1984). Although talc is more stable than other Mg-silicates (stevensite, sepiolite, etc), its precipitation has not been taken into consideration due to reaction kinetics, which determine that talc does not precipitate in sedimentary conditions (Birsoy, 2002). Saturation limits are illustrated graphically in two dimensions as a function of $\log \left[\mathrm{aMg}_{\mathrm{M}+} /\left(\mathrm{a}_{\mathrm{H}}\right)^{2}\right]$ vs. $\log \left[\mathrm{a}_{4} \mathrm{SiO}_{4}{ }^{\circ}\right]$ for stevensite and sepiolite, $\log \left[\mathrm{a}_{\mathrm{Na}} / \mathrm{a}_{\mathrm{H}}\right]$ vs. $\log \left[\mathrm{a}_{4} \mathrm{SiO}_{4}{ }^{\circ}\right]$ for $\mathrm{Na}^{-}$ silicates, or a combination for mixed $\mathrm{Na}$ - and $\mathrm{Mg}$-minerals (like saponite) according to their stoichiometry ("a" denotes activity). Components not shown on the graphs such as $\log \left[\mathrm{a}_{\mathrm{Al} 3+} /\left(\mathrm{a}_{\mathrm{H}+}\right)^{3}\right]$ were assigned as the activity ratio of saturated kaolinite. The method of calculating activity diagrams has been described in detail elsewhere (Garrels and Christ, 1965; Bowers et al., 1984) and we are using the same thermodynamic database. The solubilities of quartz, amorphous silica, $\mathrm{MgO}$, brucite, magnesite, and dolomite are also plotted as dashed lines because they are phases commonly associated with silicates in this type of alkaline environment.

\section{RESULTS AND DISCUSSION}

\section{Soil characterization}

The soil is mostly sandy, with sand values commonly higher than $80 \mathrm{wt} \%$. The total clay is mainly concentrated in the horizons $2(8.5 \mathrm{wt} \%)$ and $6(10$ to $19 \mathrm{wt} \%)$ (Table 1). The former is situated on the surface, close to the centre of the lake depression, and is characterized by dark colors due to the accumulation of slightly to moderately decomposed algae. The latter is the deepest soil horizon sampled and is identified as the green, sandy loam horizon always associated with the alkaline-saline lakes of Nhecolândia (Barbiero et al., 2007) (Figure 3). Horizon 6 also has a very to extremely hard dry consistence and firm to extremely firm moist consistence, being probably cemented by amorphous silica. Soil pH is strongly alkaline, with most of the measurements being higher than 9. However, lower values (as low as 5.4) are found close to the sand hill (Pedons 1 and 2), in the highest topographical position of the toposequence (Table 1). Electrical conductivity (EC) values present a wide range (from 0.3 to $43.0 \mathrm{dS} / \mathrm{m}$ ), but are highest toward the saline lake (Table 1). The surface water level of the lake 
varies throughout the year according to the watertable dynamics (Figure 3): from November to March (wet season), the level is high and the water commonly covers Pedons 3, 4, and 5; from April to October (dry season), the level goes down, exposing Pedons 3 and 4, and Pedon 5 only during severe drought or at the very end of the dry season.
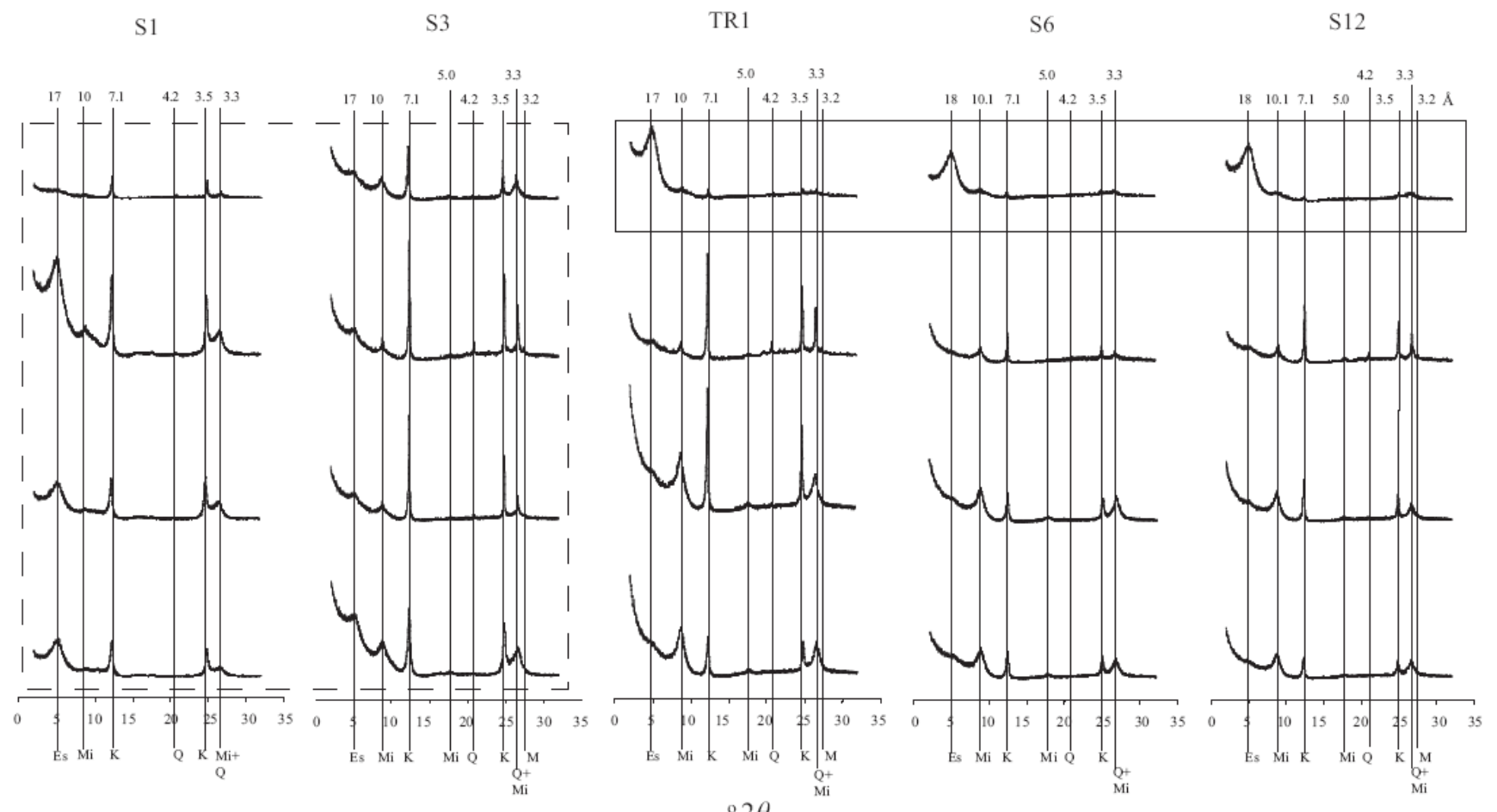

Figure 4. EG solvated peaks of fine clay fraction along the toposequence T1. Main minerals: Smsmectite, Mi-mica, and K-kaolinite; traces: M-microcline, and Q-quartz. Square (dashed line): upper zone of smectite concentration; rectangle (solid line): lower zone of smectite concentration.

\section{$X$-ray characterization}

X-ray diffraction patterns of coarse clay indicate an overwhelming dominance of kaolinite and quartz, and traces of mica, calcite, microcline, and albite (data not shown). The fine clay fraction is dominated by smectite, mica, and kaolinite and has traces of quartz and microcline (Figure 4). Smectite was identified by a shift of the 001 peak from the range of 14.1 to $15.3 \AA$ for $\mathrm{Mg}$-saturated samples, to the range of 17.0 to $18.7 \AA$ for ethylene glycol solvated (EG) samples, and by the shift of the peak to $\sim 10.0 \AA$ after heating the samples at $350^{\circ} \mathrm{C}$. Semi-quantitative results for fine-clay minerals along the toposequence show assemblages with substantial percentages of smectite in two different zones (Table 2; Figure 3): an upper zone - all horizons of Pedons 1 and 2, both located in the area rarely reached by the surface water level of the alkaline-saline lake; and a lower zone - horizon 1 and 2 of Pedons 3, 4, and 5, which are within the area of seasonal water level variation of the lake. The fine clay assemblages of the lower zone present the highest percentages of smectite (69 to 73\%). From now on, the terms "upper zone" and "lower zone" will be referred to throughout the text. The broadening of all the studied smectite peaks accompanied by high background at low angles (Figure 4) may indicate small size of coherent scattering domains of individual smectite crystals (Moore and Reynolds, 1997; Cuevas et al., 2003) and/or interstratification between smectite and another clay mineral (Moore and Reynolds, 1997; Tettenhorst and Moore, 1978). Both of these conditions are probably present in the study area. Estimation of smectite crystallite size from EG patterns using the Scherrer equation showed 
small crystallites, with sizes ranging from 103 to $220 \AA$. Additionally, random interstratification of smectite with mica and vermiculite was detected in the upper zone. The mixed-layer mica-smectite was identified in most slides from this zone (Pedon 1, horizons 1, 3, 5, 6; Pedon 2, horizons 5 and 6) by the partial coalescence of the $\mathrm{d}_{001}$ mica and smectite peaks in $\mathrm{K}$ - and Mg-saturated patterns accompanied by a clear separation of these peaks in the EG solvated patterns (Figure 5). Vermiculite-smectite interstratification was suggested by the full or partial collapse of smectite peaks to $10.0 \AA$ in some airdried K-saturated samples (Pedons 1 and 2, horizons 1 and 6) (Figure 5), behavior not expected for pure smectite end-members but typical of vermiculites (Badraoui et al., 1987; Douglas, 1989; Kohut and Dudas, 1994; Moore and Reynolds, 1997). XRD patterns from randomly oriented samples of fine clay display different 060 diffraction peaks for the two main zones of smectite concentration. The $1.52 \AA$ peak indicates a trioctahedral domain in all the samples of the lower zone, which is marked by the seasonal variation of the lake level, while peaks between $1.49-1.50 \AA$ indicate a dioctahedral character in all the samples of the upper zone, which is rarely reached by the variation of the lake level. The value of $1.52 \AA$ may indicate stevensite (Decarreau, 1980) and/or saponite (Moore and Reynolds, 1997) and 1.49-1.50 $\AA$ may indicate montmorillonite, kaolinite, and/or illite (Moore and Reynolds, 1997). Thus, the 060 peaks suggest the occurrence of different types of smectite along the toposequence.

Fine Clay - Pedon 2, horizon 6 (upper zone)

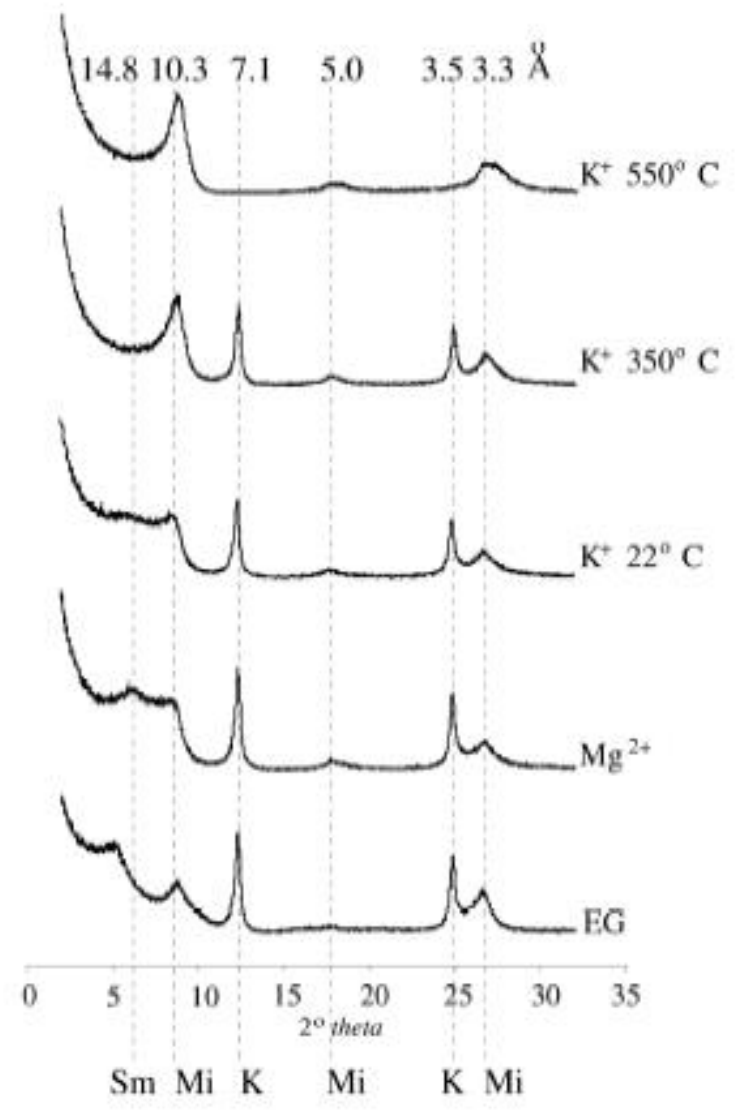

Figure 5. Example of smectite peaks behavior under different treatments: partial coalescence of the door mica and smectite peaks in $\mathrm{K}$ and $\mathrm{Mg}$-saturated patterns, clear separation of these peaks in the EG solvated sample, and full or partial collapse of dool smectite peak to $10.0 \AA$ in K-saturated sample. 


\section{Major chemical composition and structural formulas of smectites}

ICP-MS analysis of major elements in the fine clay fraction shows dominance of $\mathrm{Si}$ and $\mathrm{Al}$ in samples of the upper zone and $\mathrm{Si}$ and $\mathrm{Mg}$ in samples of the lower zone (Table 3). It suggests that $\mathrm{Al}$ and $\mathrm{Mg}$ are the main cations of the octahedral sheet in the upper and lower zone, respectively, which corroborate with the dominance of dioctahedral smectites in the former and trioctahedral smectites in the latter. In the lower zone, the average $\mathrm{Mg}$ is 6.5 times higher and the average $\mathrm{Al}$ is 4.5 times lower than the average $\mathrm{Mg}$ and $\mathrm{Al}$ of all other analyzed samples. TEM/EDS analysis of individual smectite particles (Table 4) confirms the trend pointed out by the 060 XRD patterns and ICP-MS analysis. The crystal representing the upper zone (number 1, Table 4), where dioctahedral minerals predominate, has comparatively higher values of $\mathrm{Al}_{2} \mathrm{O}_{3}(35 \mathrm{wt} \%$ ) while crystals of the lower zone (numbers 2 to 6 , Table 4 ), where clays with trioctahedral domain prevail, have comparatively higher values of $\mathrm{MgO}$ (16 to 23 wt\%). In the upper zone, the calculated chemical formula (number 1, Table 4) indicates an excess of negative charge in the tetrahedral sheet, which is a typical characteristic of both the dioctahedral smectites beidellite and nontronite (Reid-Soukup and Ulery, 2002).

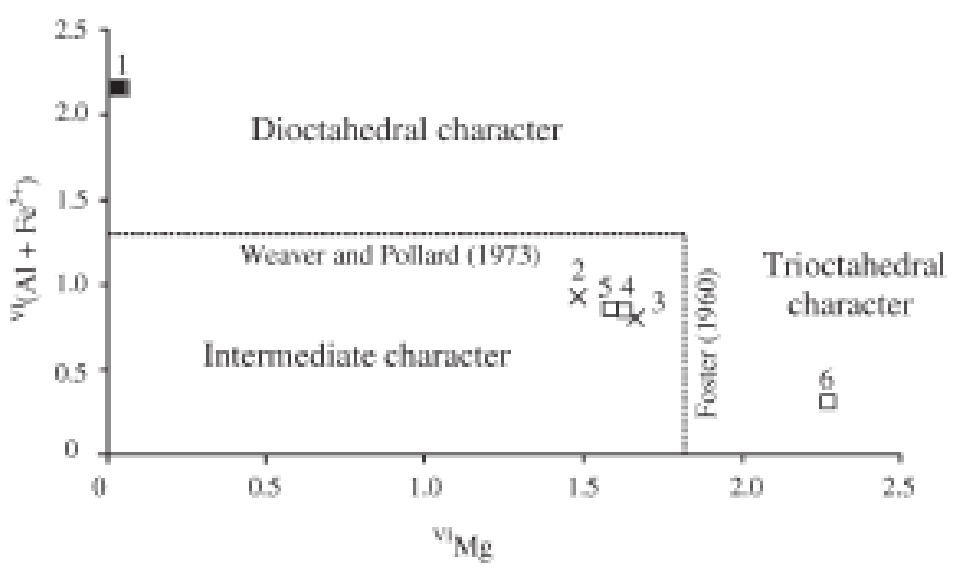

Figure 6. Diagram showing dioctahedral, trioctahedral, and intermediate character of the smectite formulas. Symbols: Full square - Pedon 1, horizon 6 (upper zone; formula number 1-Table 4); XPedon 4, horizon 2 (lower zone; formulas numbers 2 and 3-Table 4); Empty square - Pedon 5, horizon 2 (lower zone; formulas numbers 4, 5, and 6-Table 4).

The main difference between these two phases is the predominant octahedral cation: Al in beidellite and $\mathrm{Fe}^{3+}$ in nontronite. Iron substitution of octahedral $\mathrm{Al}$ in beidellite is very low, commonly less than 0.1 atoms per unit formula on the basis of 22 oxygens (apuf/22) (Güven, 1988). Predominance of $\mathrm{Al}$ in the octahedral sheet and an amount of $\mathrm{Fe}^{3+}$ of about 0.5 apuf/22 qualify the specimen listed as number 1 in Table 4 as iron-rich beidellite (ferribeidellite), an intermediate mineral commonly reported in the literature (e.g. Aoki and Kohyama, 1991; Mayayo et al., 2000). It is noticeable that the calculated chemical formula of this ferribeidellite (number 1, Table 4) has a sum of octahedral cations greater than 2.0 apuf/22. The following explanations can be proposed: 1) interstratification of ferribeidellite with mica, as indicated in the upper zone by the XRD patterns (Figure 5); 2) presence of some hydroxyl-Al, -Fe in the interlayer position, which can occur in beidellites when tetrahedral Al is larger than 0.5 apuf/22 (Weaver and Pollard, 1973), such as in the studied ferribeidellite; and/or 3) presence of free-iron oxides, which were not removed during the clay preparation. Interstratification of ferribeidellite with a trioctahedral clay is probably not occurring because TEM/EDS analysis of the individual crystal of ferribeidellite (number 1, Table 4) reveals low amounts of $\mathrm{MgO}(1.3 \%)$. Weaver and Pollard (1973) also rejected the hypothesis of some interlayered trioctahedral sheets in beidellites with high octahedral sum because of the low total of $\mathrm{Mg}$ of the analyzed samples, which are compatible 
with the amount found in our sample. In the lower zone, chemical formulas suggest presence of two different Mg-smectites. In one group (numbers 3 and 6, Table 4), there is zero, or a very small amount of tetrahedral $\mathrm{Al}$ and an excess of negative charge in the octahedral sheets. In the other group (numbers 2, 4, and 5, Table 4), the Al contents in the tetrahedral sheets are higher, slightly increasing the contribution of tetrahedral charge. The total amount of Al is also higher in this second group. Saponite and stevensite are the trioctahedral smectites rich in $\mathrm{Mg}$. Differences in chemical composition between these two end-members rely on the amount of $\mathrm{Al}$ and the consequent origin of the layer charge. Stevensite contains little or no Al-substitution in the tetrahedral sheet and most of its charge comes from vacant octahedral sites. Saponite has a higher Al substitution in the tetrahedral sheet, thus more negative tetrahedral charge (Faust and Murata, 1953; Weaver and Pollard, 1973). Based on these criteria, smectites from the first group resemble stevensite while the second group resembles saponite. However, some characteristics of these $\mathrm{Mg}$-rich formulas prevent their classification as saponite and stevensite end-members and encourage conceiving these minerals as saponitic and stevensitic smectites instead. The first is that all these samples have an amount of $\mathrm{Cl}$ not found in stevensite/saponite specimens described in the literature. $\mathrm{Cl}$ substitutes for $\mathrm{OH}^{-}$in a range of 0.14 to 0.70 apuf/22 (Table 4), having a higher mean in the closest pedon of the alkaline-saline lake (Pedon 5, horizon 2). The second is that all the Mg-rich formulas (numbers 2 to 6, Table 4) have a low total of octahedral atoms. Faust and Murata (1953) and Faust et al. (1959) pointed out that octahedral sums of stevensite are slightly lower than $3.00 \mathrm{apfu} / 22$, with these incompletely filled positions being the main mechanism of charge production in the mineral. Nevertheless, the sum of the octahedral atoms indicated by these authors (2.92 apfu/22) is considerably higher than that found in our samples (2.42 to $2.61 \mathrm{apfu} / 22)$. Two reasons are probably responsible for the low octahedral occupancy in the studied $\mathrm{Mg}$-rich smectites: 1) although the 060 XRD patterns clearly show presence of trioctahedral minerals in all samples of the lower zone, most of the structural formulas of individual crystals from these samples display an intermediate di- and tri-octahedral composition (Figure 6). Hence, the Mg-rich smectites identified seem to have a dominant trioctahedral character, but present a dioctahedral component. Kodama et al. (1988) and Pozo and Casas (1999) also attributed a similar high octahedral deficiency in saponites and stevensites to the occurrence of dioctahedral layers; 2) $\mathrm{Na}$ was not detected in the interlayer of the studied smectites, an unexpected result for minerals associated with Na-rich saline waters. This absence probably occurred due to an interference of $\mathrm{Cu}$ from the $\mathrm{Cu}$-grid of the TEM samples holder (Hover et al., 1999) and can contribute for the low octahedral sum. 


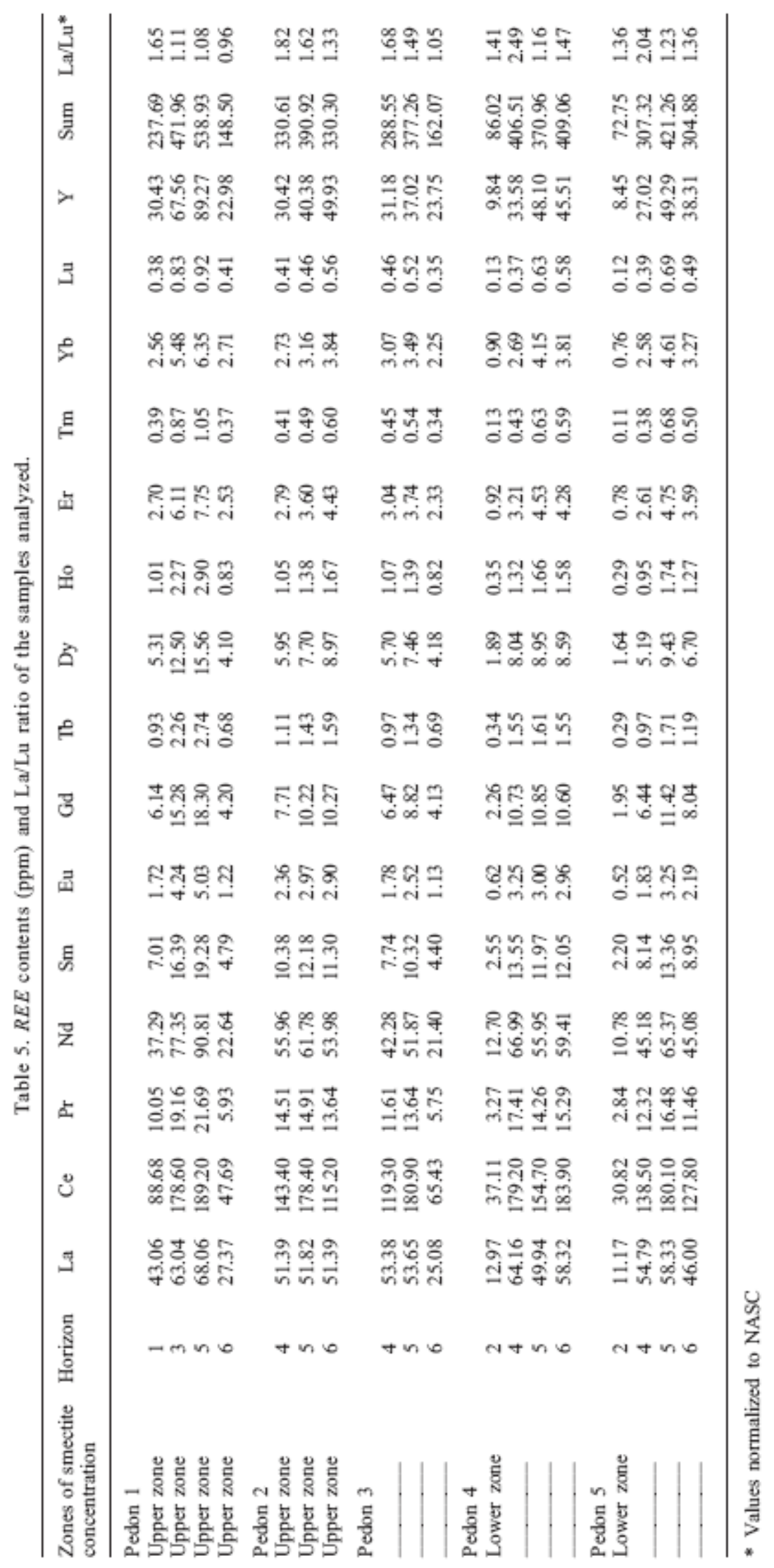



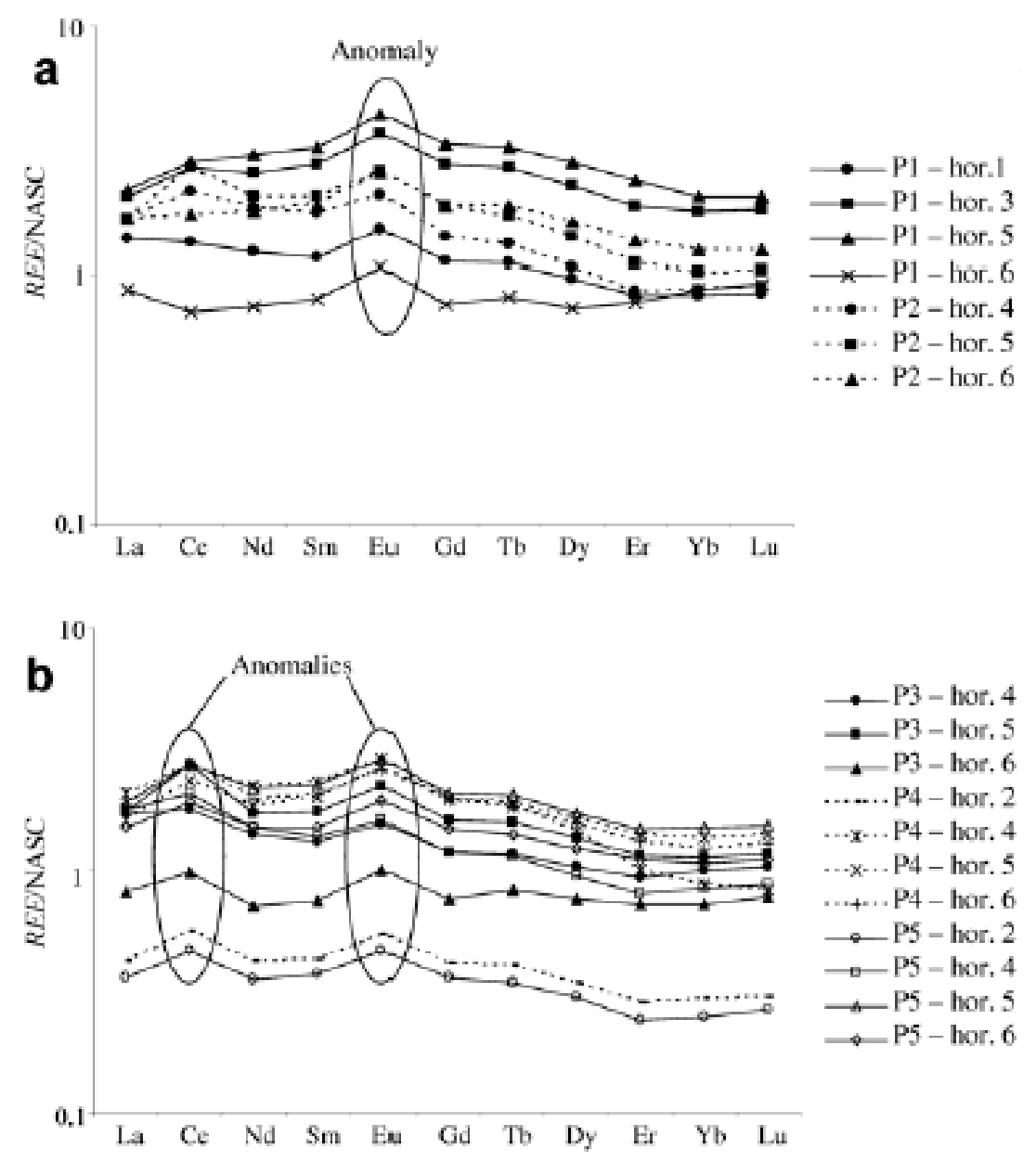

Figure 7. NASC-normalized REE patterns of: A-samples from the area rarely reached by lake level variation; and B-samples from the area seasonally reached by lake level variation.

\section{Rare earth element (REE) composition of minerals}

Samples enriched in saponitic and stevensitic smectites (lower zone) clearly have the lowest REE content of the data set (Table 5). Their sum of REEs is mostly less than half that of all other samples. Some depletion in heavy REE $(1.16<\mathrm{La} / \mathrm{Lu}<2.49)$ is observed in most of the samples (Figure 7), as expected for REE data of sediments and soils (Fleet, 1984). Ce and Eu positive anomalies, visible in Figure 7 due to a clear deviation from the slight decreasing trend toward heavy REE, are the most important in the data set. Ce anomalies are found in 12 samples, located mainly in the area seasonally flooded by the alkaline-saline lake (anomaly values near or higher than $0.10^{3}$ ), and are probably a function of alternating oxidation-reduction conditions established in the area of lake level variation (Wilde, 1996). On the other hand, Eu anomalies are observed in all the analyzed samples (anomaly

\footnotetext{
${ }^{3} \mathrm{Ce}$ and Eu anomalies have been calculated using the following formulas: log [5Ce/(4La+Sm)] (Wilde, 1996) and log $[2 \mathrm{Eu} /(\mathrm{Sm}+\mathrm{Gd})]$ (adapted from Ito et al., 2004).
} 
values equal or higher than $0.10^{4}$ ). This characteristic is probably inherited from the sediment source area and might be due to substitution for $\mathrm{Ca}$ as commonly occurs in other silicate systems.

\section{Water chemistry}

A detailed analysis of the water chemistry from the same studied transect was presented by Barbiero et al. (2007). Drastic changes are observed along the transect from where subsurface and surface waters were collected. The $\mathrm{pH}$ ranges from 3.8 to 10.2 and, among the cations, Na showed the largest standard deviation (Table 6). The concentration diagram for $\mathrm{Mg}$ against $\mathrm{Na}$, elaborated by Barbiero et al. (2007), is plotted on Figure 8. Na proved to be relevant for tracing the evaporative concentration in the studied environment. Although the plot is relatively scattered, $\mathrm{Mg}$ increases in proportion to $\mathrm{Na}$ for $\mathrm{Na}$ ranging from 0.05 to $2 \mathrm{mM}$ and then decreases for higher $\mathrm{Na}$ values. Hence, $\mathrm{Mg}$ does not have a conservative behavior and it apparently undergoes geochemical control through the precipitation of a solid phase during the concentration process. This evolution is in agreement with the simulation of evapo-concentration and precipitation of $\mathrm{Mg}$-calcite and a $\mathrm{Mg}$-silicate, represented by the solid line in Figure 8 (Barbiero et al., 2007). Freshwaters are clearly undersaturated with respect to $\mathrm{Mg}$ silicates such as saponite (Figure 9a), stevensite, and sepiolite (Figure 9b), whereas saline waters are at equilibrium or slightly oversaturated. Therefore, the formation of $\mathrm{Mg}$-silicates is possible in this environment from saline solutions. Saline solutions also reached saturation with respect to kenyaite $\mathrm{Na}_{2} \mathrm{Si}_{22} \mathrm{O}_{41}(\mathrm{OH})_{8} \cdot 6\left(\mathrm{H}_{2} \mathrm{O}\right)$ and magadiite $\mathrm{NaSi}_{7} \mathrm{O}_{13}(\mathrm{OH})_{3} \cdot 4\left(\mathrm{H}_{2} \mathrm{O}\right)$ (Figure 9c). Although these $\mathrm{Na}-$ silicates have not been identified in the field due to the absence of a specific sampling, they are typical silicates of alkaline environments and they may fleetingly form during the dry season.

Table 6. Descriptive statistics of the major ions of waters.

\begin{tabular}{|c|c|c|c|c|c|c|}
\hline Variable & Unit & Average value & Minimum & Maximum & $\begin{array}{c}\text { Variance } \\
(\mathrm{v})^{*}\end{array}$ & $\begin{array}{l}\text { Standard } \\
\text { deviation }\end{array}$ \\
\hline $\mathrm{pH}$ & - & 7.49 & 3.77 & 10.18 & 1.86 & 1.36 \\
\hline $\begin{array}{l}\text { Carbonate } \\
\text { alkalinity }\end{array}$ & $\left(\mathrm{eq} \mathrm{L}^{-1}\right.$ ) & $0.365 \times 10^{-1}$ & $-0.45 \times 10^{-3}$ & 0.941 & $0.122 \times 10^{-1}$ & 0.11 \\
\hline $\mathrm{K}^{+}$ & $\left(\mathrm{eq} \mathrm{L}^{-1}\right.$ ) & $0.861 \times 10^{-2}$ & $0.500 \times 10^{-4}$ & 0.317 & $0.107 \times 10^{-2}$ & $0.327 \times 10^{-1}$ \\
\hline $\mathrm{Na}^{+}$ & $\left(\mathrm{eq} \mathrm{L}^{-1}\right)$ & $0.545 \times 10^{-1}$ & $0.250 \times 10^{-4}$ & 1.16 & $0.197 \times 10^{-1}$ & 0.14 \\
\hline $\mathrm{Ca}^{2+}$ & $\left(\mathrm{eq} \mathrm{L}^{-1}\right)$ & $0.253 \times 10^{-3}$ & $0.100 \times 10^{-5}$ & $0.147 \times 10^{-2}$ & $0.840 \times 10^{-7}$ & $0.290 \times 10^{-3}$ \\
\hline $\mathrm{Mg}^{2+}$ & $\left(\mathrm{eq} \mathrm{L}^{-1}\right)$ & $0.177 \times 10^{-3}$ & $0.500 \times 10^{-6}$ & $0.164 \times 10^{-2}$ & $0.922 \times 10^{-7}$ & $0.304 \times 10^{-3}$ \\
\hline $\mathrm{Cl}^{-}$ & $\left(\mathrm{eq} \mathrm{L}^{-1}\right)$ & $0.222 \times 10^{-1}$ & $0.11 \times 10^{-4}$ & 0.393 & $0.242 \times 10^{-2}$ & $0.492 \times 10^{-1}$ \\
\hline $\mathrm{SO}_{4}^{2-}$ & $\left(\mathrm{eq} \mathrm{L}^{-1}\right)$ & $0.207 \times 10^{-3}$ & $0.500 \times 10^{-6}$ & $0.277 \times 10^{-2}$ & $0.225 \times 10^{-6}$ & $0.475 \times 10^{-3}$ \\
\hline
\end{tabular}

$* v=\frac{1}{n} \sum_{i=1}^{n}\left(x_{i}-\bar{x}\right)^{2} \quad \bar{x}=\frac{1}{n} \sum_{i=1}^{n} x_{i}$

\section{Genesis of ferribeidellite}

XRD data from samples containing dioctahedral smectite (upper zone) suggest some degree of mica interstratification in most of the samples (Figure 5). Smectites transformed from micas are likely to be tetrahedrally substituted (Borchardt, 1989), just like the ferribeidellite described in this paper (Table 4, Pedon 1-horizon 6, n.1). Furthermore, the micas in the studied toposequence are also ironenriched specimens, consisting mostly of neoformed Fe-illite and glauconite, both interstratified with smectite layers (Furquim et al., 2004). Thus, ferribeidellite may originate from transformation of the neoformed micas in the upper zone. The seasonal variation of the lake level and the consequent wetting-drying cycles of the adjacent soils are probably contributing to the transformation of mica in the upper zone. Scott and Smith (1968) verified that drying can release K in the inner mica core either by separating silicate layers across the entire particle or by proliferating cracks from the edge to the inner core of the particle. The former mechanism apparently is the most common in clay-size micas 
(Fanning et al., 1989). Because the upper zone is in the highest area of the studied toposequence, it is subjected to longer drying periods and, consequently, results in more K-release from mica particles. A mixed-layer vermiculite-smectite is also present in horizons 1 and 6 of the upper zone, as indicated by the total or partial collapse of the smectite peak to $10 \AA$ in air-dried K-saturated samples (Figure 5). Vermiculite has been commonly reported as an intermediate phase in the transformation of mica toward smectite in soils (Crawford et al., 1983; Badraoui et al., 1987; Ransom et al., 1988). Indeed, stability diagram predictions have shown that vermiculites are considered unstable and then a shortlived transition state in the process of mica transformation under room temperature and pressure conditions (Kittrick, 1973). Experiments of transformation of trioctahedral (phlogopite, biotite) and dioctahedral micas (phengite, sericite, muscovite, glauconite, and illite), carried out by Robert (1973), showed that only illites and glauconites transformed to smectites and presented vermiculites as an intermediate phase. Thus, the formation of vermiculite is possible in the study area before the transformation of interstratified Fe-illite and glauconite into ferribeidellite is complete.

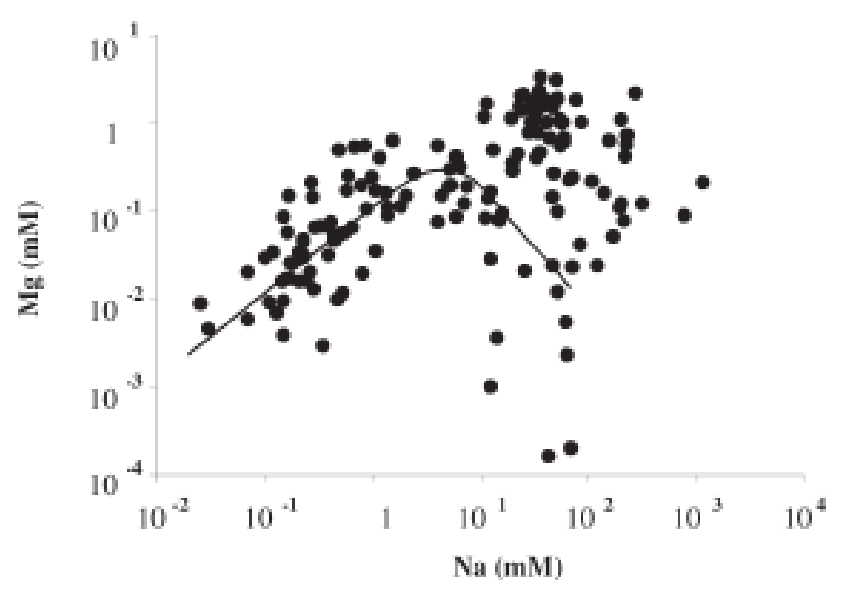

Figure 8. Concentration diagram showing the evolution of $\mathrm{Mg}$ amounts during concentration of waters by evaporation. Na amounts represent the concentration factor. The solid line denotes the simulation of evaporation with precipitation of $\mathrm{Mg}$-calcite and a Mg-silicate (sepiolite) (Barbiero et al., 2007).

\section{Genesis of saponitic and stevensitic smectites}

Analysis of the REE distribution along the toposequence (Table 5) gives interesting clues about the genesis of these dominantly trioctahedral smectites. Most natural waters have extremely low REE concentrations in comparison to rocks (McLennan, 1989). Because most of the REEs remain concentrated in clay mineral structures and only minor amounts go into solution during weathering, transportation, and deposition processes (Fleet, 1984), detrital or transformed minerals are expected to have much higher REE amounts than minerals formed by direct precipitation from water. This fact has been used as a tool in the study of sediments of lacustrine environments to distinguish minerals that can be formed by chemical precipitation (sepiolite, stevensite) from those inherited (Al-smectite) or transformed (palygorskite) (Torrez Ruiz et al., 1994; López-Galindo et al., 1996; Jamoussi et al., 2003). In the present study, it is clear that samples dominated by trioctahedral smectites have much lower amounts of REE than samples where other minerals are dominant (Table 5). This evidence suggests that the saponitic and stevensitic smectites observed under and around the alkaline-saline lake are formed by chemical precipitation. The water chemistry provides two other lines of evidence that support the chemical precipitation of saponitic and stevensitic smectites found in the study area. First, the concentration diagram (Figure 8) shows that the $\mathrm{Mg}$ is not a conservative element, constantly evolving in proportion to the concentration factor (represented by $\mathrm{Na}^{+}$evolution), instead it precipitates during the concentration process. Therefore, this element can be involved in the precipitation of the Mg-smectites around the studied alkaline-saline lake. Second, the equilibrium diagrams (Figure 9a and 9b) indicate that the most saline waters are at equilibrium or oversaturated with respect to $\mathrm{Mg}$-silicates (saponite, sepiolite, stevensite). This observation reveals that these or similar minerals can originate 

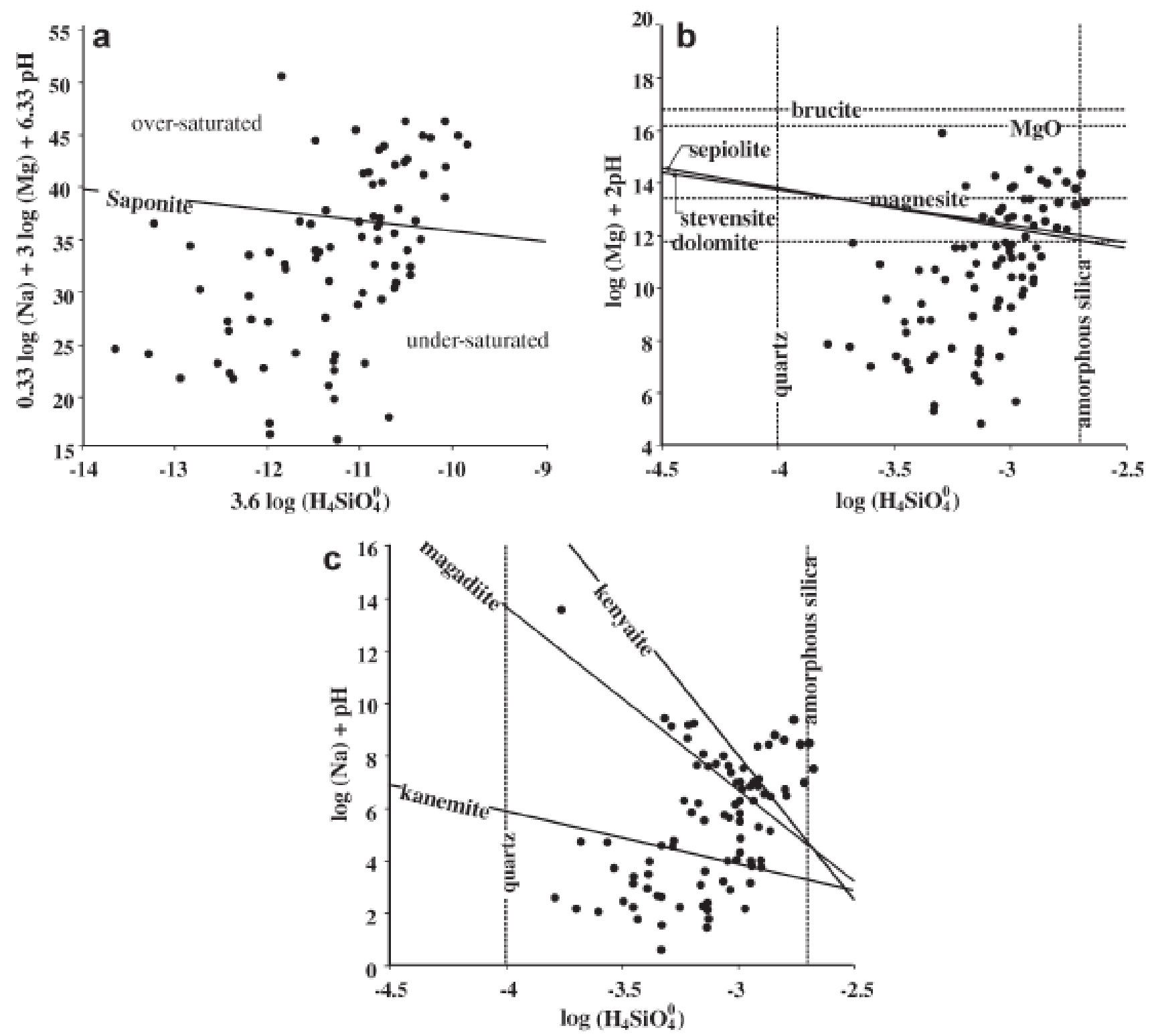

Figure 9. Diagrams showing equilibrium conditions in solution for different minerals.

More evidence of the origin of these trioctahedral smectites is given by the soil organization along the toposequence. Figure 3 shows that the soil horizons that contain $\mathrm{Mg}$-smectites (Pedon 3-horizon 1; Pedon 4-horizon 2; Pedon 5-horizon 2), are only within the area of seasonal variation of the lake level. This suggests a direct association of these minerals with the lake dynamics. The exclusive occurrence of these minerals on the surface suggests a genesis related to a direct contact to the lake water body itself and not to processes occurring beneath, within the soils. Thus, these data support our hypothesis that the saponitic and stevensitic smectites have formed by chemical precipitation directly from the lake and not by transformation of a precursor clay. Moreover, the chemical characteristics of the surface and subsurface lake water are ideal for neoformation of these $\mathrm{Mg}$-smectites (Table 6). $\mathrm{Mg}$ is essential for the $\mathrm{Mg}$-smectite neoformation. However, because the formation of $\mathrm{Mg}$-smectites also involves exchange of protons, the saturation with respect to $\mathrm{Mg}$-smectite minerals is easier under high $\mathrm{pH}$ conditions (Siffert, 1962), which is the case in the study area. Evidence of precipitation of $\mathrm{Mg}$ - 
smectites with intermediate composition between di- and tri-octahedral sheets was also showed by Tettenhorst and Moore (1978) and Pozo and Casas (1999) in lacustrine Tertiary sediments.

\section{CONCLUSIONS}

This work shows that the dioctahedral and dominantly trioctahedral smectites present under and around the studied alkaline-saline lake are formed by different processes. The ferribeidellite transforms from a precursor clay mineral (Fe-enriched micas), a mechanism of genesis commonly reported for dioctahedral smectites of alkaline-saline environments. On the other hand, several lines of evidence indicate that saponitic and stevensitic smectites have been formed by chemical precipitation from the water column of the alkaline-saline lake, contrasting with other genetic pathways described in the literature. As postulated by Barbiero et al. (2002), the current evaporative concentration of waters from Nhecolândia is probably promoting precipitation of some elements from the more saline solutions and their consequent participation in authigenic mineral phases, processes that would be responsible for most of the chemical variability between fresh and saline waters. Thus, the control of $\mathrm{Mg}$ from the waters and the neoformation of $\mathrm{Mg}$-smectites on the shore of the alkaline-saline lake reinforce the attribution of the saline water of Nhecolândia to present-day processes of evaporation and weaken the traditional and widely accepted hypothesis of salt inheritance from an arid period during Pleistocene (Tricart, 1982; Ab'Saber, 1988).

\section{ACKNOWLEDGMENTS}

The authors wish to thank Capes for the doctoral fellowship to S.A.C.F. and for the financial support to the research through a Capes-Cofecub cooperation (412/03); Dr. Arnaldo Sakamoto, Dr. Rosely Pacheco Dias Ferreira, Dr. Sônia Furian, Ary Tavares, undergraduate and graduate students of University of Mato Grosso do Sul (UFMS), and employees of the Nhumirim Farm for their assistance in the field; Paul Sternberg and Marcos Pinheiro for general help with the laboratory work; Dr. Richard Morris and Dr. Douglas Ming for Mössbauer spectroscopy analyses; and Dr. Krassimir Bozhilov for TEM assistance.

\section{REFERENCES}

Ab'Saber, A.N. (1988) O Pantanal Mato-Grossense e a Teoria dos Refúgios. Revista Brasileira de Geografia, 50, 9-57.

Akbulut, A. and Kadir, S. (2003) The Geology and origin of sepiolite, palygorskite and saponite in Neogene lacustrine sediments of the Serinhisar-Acipayam Basin, Denizli, Sw Turkey. Clays and Clay Minerals, 51, 279-292.

Alfonsi, R.R. and Camargo, M.B.P. (1986) Condições climáticas para a região do Pantanal Matogrossense. Pp. 105-106 in: Anais do $1^{\circ}$ Simpósio sobre Recursos Naturais e Sócio-Econômicos do Pantanal. Corumbá.

Alvarenga, S.M., Brasil, A.E., Pinheiro, R., Kux, H.J.H. (1984) Estudo Geomorfológico Aplicado à Bacia do Alto Rio Paraguai e Pantanais Matogrossenses. Boletim Técnico Projeto Radambrasil, 1, 187 pp.

Amaral Filho, Z.P. (1986) Solos do Pantanal Matogrossense. Pp. 91-103 in: Anais do $1^{o}$ Simpósio sobre Recursos Naturais e Sócio-Econômicos do Pantanal. Corumbá. 
Anderson, J.U., (1963). An improved pretreatement for mineralogical analysis of samples containing organic matter. Clays and Clay Minerals, 10, 380-388.

Aoki, S and Kohyama, N. (1991) The vertical change in clay mineral composition and chemical characteristics of smectite in sediment cores from the southern part of the Central Pacific Basin. Marine Geology, 90, 41-49.

Banfield, J. F., Jones, B.F.,Veblen, D.R. (1991) An AEM-TEM study of weathering and diagenesis, Abert Lake, Oregon: II. Diagenetic modification of the sedimentary assemblage. Geochimica et Cosmochimica Acta, 55, 2795-2810.

Barbiero, L., Furian, S., Queiroz Neto, J.P., Ciornei, G., Sakamoto, A.Y., Capellari, B.; Fernandes, E., Vallès, V. (2002) Geochemistry of water and ground water in the Nhecolândia, Pantanal of Mato Grosso, Brazil: variability and associated processes. Wetlands, 22, 528-540.

Barbiero L., Furquim, S.A.C., Vallès, V., Furian, S., Sakamoto, A., Rezende Filho, A., Fort, M. (2007) Natural Arsenic in Groundwater and Alkaline Lakes at the Upper Paraguay Basin, Pantanal, Brazil. Pp. 101-126 in: Arsenic in Soil and Groundwater Environment: Biogeochemical Interactions, Health Effects and Remediation (P. Bhattacharya, A.B. Mukherjee, J. Bundschuh, R. Zevenhoven, R.H. Loeppert, editors), Trace Metals and Other Contaminants in the Environment series, 9, Elsevier.

Badraoui, M., Bloom, P.R., Rust, R.H. (1987) Occurrence of high-charge beidellite in a vertic Haplaquoll of northwestern Minnesota. Soil Science Society of America Journal, 51, 813-818.

Birsoy, R. (2002) Formation of sepiolite-palygorskite and related minerals from solution. Clays and Clay Minerals, 50, 736-745.

Biscaye, P. (1965) Mineralogy and sedimentation of recent deep-seaclay in the Atlantic Ocean and adjacent seas and oceans. Geological Society of America Bulletin, 76, 803-832.

Borchardt, G. (1989) Smectites. Pp. 675-728 in: Minerals in Soil Environments (J.B. Dixon and S.B Weed, editors). Soil Science Society of America Book Series, 1, Soil Science Society of America, Inc., Madison.

Bowers, T.S., Jackson, K.J., Helgeson, H.C. (1984) Equilibrium Activity Diagrams for Coexisting Minerals and Aqueous Solutions at Pressures and Temperatures to $5 \mathrm{~kb}$ and $600^{\circ} \mathrm{C}$. Springer-Verlag, New York, 397 pp.

Crawford, T.W., Whittig, L.D.,; Begg, E.L., Huntington, G.L. (1983) Eolian influence on development and weathering of some soils of Point Reyes Peninsula, California. Soil Science Society of America Journal, 47, 1179-1185.

Cuevas, J., De La Villa, V., Ramirez, S., Petit, S., Meunier, A., Leguey, S. (2003) Chemistry of Mg smectites in lacustrine sediments from the Vicalvaro sepiolite deposit, Madrid Neogene Basin (Spain). Clays and Clay Minerals, 51, 457:472.

Cunha, N.G. (1980) Considerações sobre os solos da sub-região da Nhecolândia, Pantanal MatoGrossense. Circular Técnica Embrapa, 1, 1-45.

Darragi, F. and Tardy, Y. (1987) Authigenic trioctahedral smectites controlling pH, alkalinity, silica and magnesium concentrations in alkaline lakes. Chemical Geology, 63, 59-72.

Decarreau, A. (1980) Cristallogène expérimentale des smectites magnésiennes: hectorite, stévensite. Bulletin de Minéralogie, 103, 579-590. 
Del'Arco, J.O., Silva, R.H., Tarapanoff, I., Freire, F.A., Pereira, L.G.M., Souza, S.L., Luz, D.S., Palmeira, R.C.B., Tassinari, C.C.G. (1982) Geologia da Folha SE.21- Corumbá e Parte da Folha SE.20. Pp. 25 a 160 in: RADAMBRASIL-Levantamento dos Recursos Naturais. Rio de Janeiro.

Douglas, L.A. (1989) Vermiculites. Pp. 635-674 in: Minerals in Soil Environment (J.B. Dixon and S.B. Weed, editors). Soil Science Society of America Book Series, 1, Soil Science Society of America, Inc., Madison.

Fanning, D.S., Vissarion, Z.K., El-Desoky, M.A. (1989) Micas. Pp. 551-634 in: Minerals in Soil Environments (J.B. Dixon \& S.B. Weed, eds). SSSA Book Series, n.1. Soil Science Society of America.

Faust, G.T and Murata, K.J. (1953) Stevensite, redefined as a member of the montmorillonite group. The American Mineralogist, 38, 973-987.

Faust, G.T., Hathaway, J.C., Millot, G. (1959) A restudy of stevensite and allied minerals. The American Mineralogist, 44, 342-370.

Fernandes, E., Sakamoto, A.Y., Queiroz Neto, J.P., Lucati, H.M., Capellari, B (1999) Le "Pantanal da Nhecolândia" Mato Grosso: Cadre Physique et Dynamique Hydrologique. Geografia fisica e Dinamica Quaternaria, 22, 13-21.

Fleet, A.J. (1984) Aqueous and sedimentary geochemistry of the rare earth elements. Pp. 343-373 in: Rare Earth Element Geochemistry (P. Henderson, editor). Developments in Geochemistry Series, 2, Elsevier.

Foster, M.D. (1960) Interpretation of the composition of trioctahedral micas. U.S. Geological Survey Professional Paper, 354 B, 11-43.

Furquim, S.A.C., Graham, R.C., Queiroz Neto, J.P., Furian, S., Barbiero, L. (2004) Fe-illite neoformation in an alkaline environment, Pantanal Wetland, Brazil. In: Proceedings of the Soil Science Society of America Annual Meeting. CD media. Seattle.

Gac, J.Y., Droubi, A., Fritz, B., Tardy,Y. (1977). Geochemical behavior of silica and magnesium during the evaporation of waters in Chad. Chemical Geology, 19, 215-228.

Garrels, R.M. and Christ, C.L. (1965) Solutions, Minerals, and Equilibria. Harper and Row, New York, $450 \mathrm{pp}$.

Godoi Filho, J.D. (1986) Aspectos Geológicos do Pantanal Mato-grossense e de sua Área de Influência. Pp. 63-76 in: Anais do $1^{o}$ Simpósio sobre Recursos Naturais e Sócio-Econômicos do Pantanal. Corumbá.

Gromet L.P., Dymek, R.F., Haskin, L.A., Korotev, R.L. (1984) The "North American shale composite": its compilation, major and trace element characteristics. Geochimica et Cosmochimica Acta, 48, 2469-2482.

Gueddari, M. (1984) Géochimie et thermodynamique des évaporites continentales. Etude du lac Natron en Tanzanie et du Chott El Jerid en Tunisie. Mémoire des Sciences Géologiques, 76, 1-143.

Güven, N. (1988) Smectites. In Bailey, S. W. (ed.) Reviews in Mineralogy, 19, 497-559.

Hillier, S. (1995) Erosion, sedimentation and sedimentary origin of clays. Pp: 162-219 in: Origin and mineralogy of clays. Clays and the environment (B. Velde, editor). Springer.

Hover, V.C., Walter, L.M., Peacor, D.R., Martini, A. (1999) Mg-smectite authigenesis in a marine evaporative environment, salina Ometepec, Baja California. Clays and Clay Minerals, 47, 252-268. 
Ito, T., Komuro, K., Hatsuya, K., Nishi, H. (2004) Chemical composition of ferromanganese micronodules in sediments at site 1216, ODP Leg 199, Paleogene equatorial transect. Pp 1-20 in: Proceedings of the Ocean Drilling Program. Scientific Results, 199 (on line publication at wwwodp.tamu.edu/publications/SR.HTML).

Jackson, M.L. (1979) Soil Chemical Analysis-Advanced Course. By author, Madison, 895 pp.

Jamoussi, F., Ben Aboud, A., López Galindo, A. (2003) Palygorskite genesis through silicate transformation in Tunisian continental Eocene deposits. Clay Minerals, 38, 187-199.

Jeans, C.V. (1984) Patterns of mineral diagenesis. Clay Minerals, 19, 263-270.

Jones, B.F. (1986) Clay mineral diagenesis in lacustrine sediments. Pp. 291-300 in: Studies in Diagenesis (F.A. Mumpton, editor). US Geological Survey Bulletin, 1578.

Kittrick, J.A. (1973) Mica-derived vermiculites as unstable intermediates. Clays and Clay Minerals, 21, 479-488.

Kodama, H., De Kimpe, C.R., Dejou, J. (1988) Ferrian saponite in a gabbro saprolite at Mont Mégantic, Quebec. Clays and Clay Minerals, 36, 102-110.

Kohut, C.K. and Dudas, M.J. (1994) Characteristics of clay minerals in saline alkaline soils in Alberta, Canada. Soil Science Society of America Journal, 58, 1260-1269.

López-Galindo, A., Ben Aboud, A., Fenoll Hach-Ali, P., Casas Ruiz, J. (1996) Mineralogical and geochemical characterization of palygorskite from Gabasa (Ne Spain). Evidence of a detrital precursor. Clay Minerals, 31, 33-44.

Mayayo, M.J., Bauluz, B., Gonzalez Lopez, J.M. (2000) Variations in the chemistry of smectites from the Calatayud Basin (NE Spain). Clay Minerals, 35, 365-374.

McLennan, S.M. (1989) Rare earth elements in sedimentary rocks: influence of provenance and sedimentary processes. Pp. 169-200 in: Geochemistry and Mineralogy of Rare Earth Elements (B.R. Lipin and G.A. McKay, editors). Reviews in Mineralogy, 21, Mineralogical Society of America, Washington, D.C.

Moore, D. and Reynolds, R.C. (1997) X-ray Diffraction and the Identification and Analysis of Clay Minerals. Oxford University Press, 378 pp.

Parkhurst, D.L. (1995) Users Guide to PHREEQC-A Computer program for speciation, reaction-path, advective-transport, and inverse geochemical calculations. U.S. Geological Survey - Water-Resources Investigations Reports, 95-4227.

Por, F.D. (1995) The Pantanal of Mato Grosso (Brazil) - World's Largest Wetland. Kluwer Academic Publishers, Dordrecht, 122 pp.

Pozo, M. and Casas, J. (1999) Origin of kerolite and associated Mg clays in palustrine-lacustrine environments. The Esquivias deposit (Neogene Madrid Basin, Spain). Clay Minerals, 34, 395-418.

Ransom, M.D., Bigham, J.M., Smeck, M.E., Jaynes, W.F. (1988) Transitional vermiculite-smectite phases in Aqualfs in southwestern Ohio. Soil Science Society of America Journal, 52, 873-880.

Reid-Soukup, D.A. and Ulery, A. (2002) Smectites. Pp. 467-499 in: Soil Mineralogy with Environmental Application (J.B. Dixon and D.G. Schulze, editors). Soil Science Society of America Book Series, 7, Soil Science Society of America, Inc., Madison.

Robert, M. (1973) The experimental transformation of mica toward smectite: relative importance of total charge and tetrahedral substitution. Clays and Clay Minerals, 21, 167-174. 
Scatchard, G. (1936) Concentrated solutions of strong electrolytes. Chemistry Review, 19, 309-327.

Scott, A.D. and Smith, S.J. (1968) Mechanism for soil potassium release by drying. Soil Science Society of America Proceedings, 32, 443-444.

Scott, D.A. (1991) Latin America and Caribbean. Pp. 85-114 in: Wetlands: A Global Perspective (C.M. and M.E. Moser, editors). Facts on File, New York.

Siffert, B. (1962) Quelques réactions de la silice en solution: la formation des argiles. Mémoires du Service de la Carte Géologique d'Alsace et de Lorraine, 21, 86 pp.

Silva, T.C. (1986) Contribuição da Geomorfologia para o Conhecimento e Valorização do Pantanal. Pp. 77-90 in: Anais do $1^{o}$ Simpósio sobre Recursos Naturais e Sócio-Econômicos do Pantanal. Corumbá.

Tettenhorst, R. and Moore Jr., G.E. (1978) Stevensite oolites from the Green River formation of Central Utah. Journal of Sedimentary Petrology, 48 ,587-594.

Theisen, A.A. and Harward, M.E. (1962) A paste method for preparation of slides for clay mineral identification by X-ray diffraction. Soil Science Society of America Proceedings , 26, 90-91.

Torrez-Ruiz, J., López-Galindo, A., Gonzalez-López, J.M., Delgado, A. (1994) Geochemistry of Spanish sepiolite-palygorskite deposits: genetic considerations based on trace elements and isotopes. Chemical Geology, 112, 221-245.

Tricart, J. (1982) El Pantanal: Un ejemplo del impacto de la Geomorfología sobre el medio ambiente. Geografia, 7, 37-50.

Vallès V., Ribolzi O., de Cockborne A.M., Cornieles M. (1996) Presentation de AQUA, logiciel de géochimie appliqué aux problèmes environnementaux. Gressap. ORSTOM, Montpellier.

Weaver, C.E. and Pollard, L.D. (1973) The Chemistry of Clay Minerals. Elsevier, Amsterdam. 213 pp.

Wilde, P. (1996) The whole-rock Ce anomaly: a potential indicator of eustatic sea-level changes in shales of the anoxic facies. Sedimentary Geology, 101, 43-53. 